\title{
AFLATOXINA E INIBIDORES BACTERIANOS NO LEITE TIPO "B") COMERCIALIZADO EM SÃO PAULO. LEVANTAMENTO DAS QUATRO MARCAS DE MAIOR CONSUMO.
}

\author{
is \\ JORGE LUIZ SEFERIN MARTINS
}

Tese apresentada à Faculdade de Saúde Pública da Universidade de São Paulo, Departamento de Nutrição, para obtenção do título de "Doutor em Saúde Pública"

Orientador:

Prof. Dr. IGNEZ SALAS MARTINS

SÃO PAULO

1984

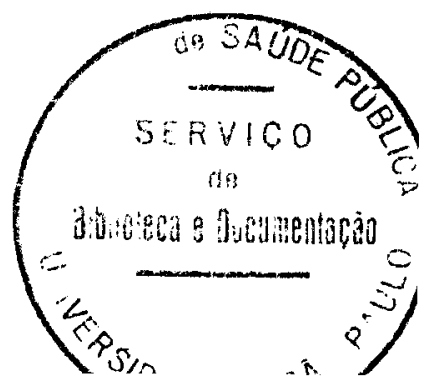


Aos meus pais, pelo constante apoio. 
A Ida, pelo amor e dedicação que sempre me proporcionou. 
Ao André Luiz, com amor. 


\section{AGRADECIMENTOS}

A Professora Dra. Ignes Salas Martins pela orientação da tese.

Ao Professor Dr. João Fernandes Magalhäes por ter permitido o uso do laboratōio da disciplina de Controle Farmacéutico de qualidade $I I$ da Faculdade de Ciências Farmacêuticas da Universidade de são Paulo, para desenvolvimento desta tese e pe la revisão.

Ao Probessor Dr. Donald Wilson pelas críticas e sugestões apresentadas e pela revisão desta tese.

A Professora Dra. Eunice Pinho de Castro e Silva pela orientação na execução da amostragem.

Ao Professor Dr. José Cézar Panetta pelas sugestões apresentadas.

A Maria Cecilia Gonzaga Ferreira pela revisão das referên cias bibliogrāficas.

A Märcia Vallim, Shirlei V. M. Gonçalves Silva, pelos servicos prestados.

Ao Professor Henrique Vicente Della Rosa pelo apoio recebido.

As colegas Erika Rosa Maria Hackmann e Maria Inês Rocha Miritello Santoro pela amizade.

Ao Dr. Oswaldo Luiz Marmo, da Cia. Industrial e Comercial Brasileira de Produtos alimentares, pelo fornecimento do padrão de aflatoxina.

Ao Dr. Bruno Nishikawara, da chimie Test Produtos Químicos Ltda., pelo fornecimento dos meios de cultura. 
Ao or. Antônio Felizes Pinto, das Indüstrias Farmacêuticas Fontora wyeth S.A., pelo fornecimento de penicilinase e do padrão de penicilina.

A CAPES e Biblioteca da FSP/USP pelo apoio bibliogrāfico du rante o desenvolvimento da tese.

A Professora Dra. Takako Saito e aos auxiliares José Silves tre Campos Nogueira e Horilde de Oliveira Castaldi da disciplina de controle Biológico de Rualidade da Faculdade de Ciências Farmacêuticas da universidade de são Paulo, pelo empréstimo de material e serviços prestados. 


\section{IND I CE}

pāg.

RESUMO $x i$

SUMMARY

$x i i j$

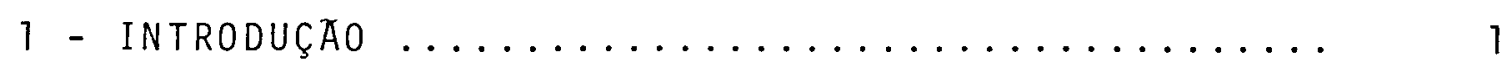

$1.1-$ Aflatoxinas .................. 4

1.2 - Antibióticos .................. 15

1.3 - Agua 0xigenada, Cloro e Formol ........ 21

2 - OBJETIVO ....................... 27

3 - MAterial E metodos ................... 28

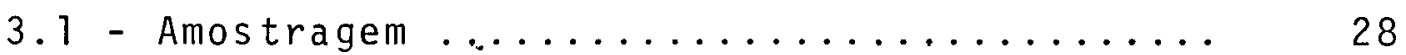

3.2 - Determinação de aflatoxina .......... 33

3.3 - Detecção de antibiōticos ............. 36

3.4 - Identificação de ãgua oxigenada ........ 38

3.5 - Identificação de formol ............ 38

3.6 - Identificação de cloro ............. 39

$4-$ RESULTADOS ...................... 40

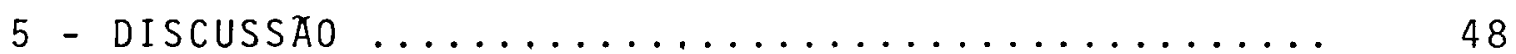

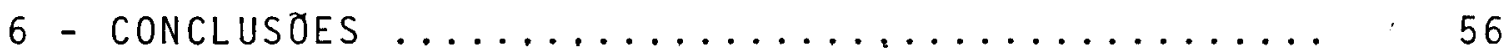

7 - REFERENCIAS BIBLIOGRAFICAS .............. 58 
INDICE DE ILUSTRAÇOES

pāg .

FIgURA 1 - Plano de amostragem - Relação dos dias correspondentes ao 10 periodo ........

FIgURA 2 - Plano de amostragem - Relação dos dias correspondentes ao 20 período .........

FIGURA 3 - Plano para sorteio das possiveis amostras sistemáticas de cada estrato ....

FIgURA 4 - Esquema do cromatograma bidimensio nal $\ldots \ldots \ldots \ldots \ldots \ldots \ldots \ldots \ldots \ldots \ldots$ 


\section{INDICE DE TABELAS}

pāg .

TABELA 1 - Exemplos de incidéncia de aflatoxina em

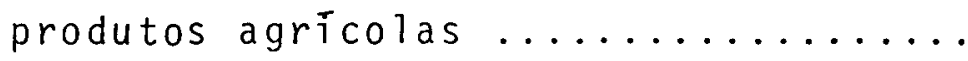

TABELA 2 - Limites de tolerāncia para aflatoxina

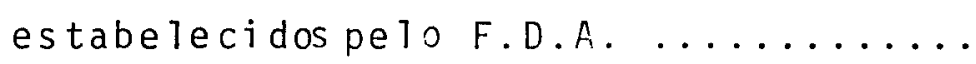

TABELA 3 - Limites de tolerāncia para aflatoxina em alimentos e rações estabelecidos pe-

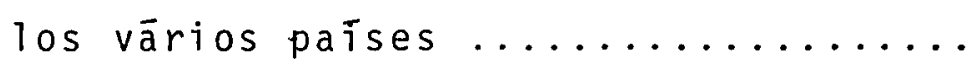

TABELA 4 - Incidência de aflatoxina nas amostras de leite correspondente as quatro marcas de maior consumo analisadas no 70 período $(14.06 .82$ a 31.10 .82$) \ldots \ldots$

TÄBELA 5 - Incidência de inibidores bacterianos nas amostras de leite correspondente as quatro marcas de maior consumo analisadas no 19 período (14.06.82 a 31.10 .82$)$.. 
TABELA 6 - Incidéncia de inibidores bacterianos nas amostras de leite correspondente as qua tro marcas de maior consumo analisadas no 20 período (01.11.82 a 20.03.82) ...

TABELA 7 - Incidencia de penicilina nas amostras de leite correspondente as quatro marcas de maior consumo analisadas no 10 período $(14.06 .82$ a 31.10 .82$) \ldots \ldots \ldots \ldots \ldots$

TABELA 8 - Incidencia de penicilina nas amostras de leite correspondente as quatro marcas de maior consumo analisadas no 20 perío do $(01.11 .82$. a 20.03 .82$) \ldots \ldots \ldots \ldots$

TABELA 9 - Incidência de inibidores não identifica dos nas amostras de leite correspondente a quatro marcas de maior consumo ana lisadas no 10 período $(14.06 .82$ a 31 .

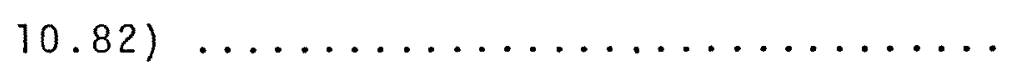


TABELA 10 - Incidência de inibidores não identifica dos nas amostras de leite corresponden te as quatro marcas de maior consumo ana 1 isadas no 20 período $(01.11 .82$ a 20 .

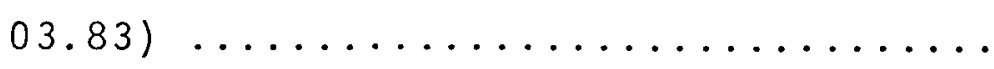

TABELA 11 - Incidência de água oxigenada, formol e cloro nas amostras de leite correspondente as quatro marcas de maior consumo analisadas no 10 período $(04.06 .82$ a 31 .

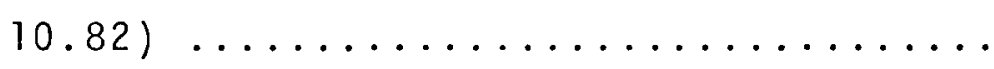

TABELA 12 - Incidéncia de àgua oxigenada, formol e cloro nas amostras de leite correspondente as quatro marcas de maior consumo analisadas no 20 período $(01.11 .82$ a

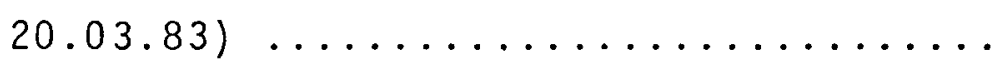


RESUMO

No leite tipo "B" comercializado em São Paulo foram pesquisados a presença de aflatoxina $M_{1}$ e de inibidores bacterianos (penicilina, āgua oxigenada, formol e cloro).

As amostras de leite utilizadas foram provenientes das quatro marcas de maior consumo pela população de São Pau 10 .

0 trabalho constituiu-se em um estudo longitudinal, com amostragem probabilistica, dividido em dois períodos iguais de 140 dias com 224 amostras analisadas.

No primeiro período, de 14 de junho a 31 de outubro de 1982, foram pesquisados todos os contaminantes propostos. No segundo período, de 01 de novembro de 1982 a 30 de março de 1983, a aflatoxina não foi pesquisada, pois, como sofre influéncia sazonal, há maior possibilidade de ser encontrada nos meses de temperaturas mais baixas.

A aflatoxina, embora em baixos nīveis e em pequena proporção $(1,8 \%)$, fez-se presente nas quatro marcas.

Foi constatada alta prevaléncia de inibidores bacterianos. No primeiro e no segundo período a proporção foi de $4,95 \%$ e $4,50 \%$ respectivamente.

No primeiro período a incidéncia de resíduos de pe nicilina e de inibidores não identificados foi de 0,9\%, e de $3,6 \%$ respectivamente. No segundo foi de $0,45 \%$ e de $3,15 \%$. 
Houve uma baixa proporção de amostras com ägua oxigenada e formol, e ausência de cloro.

De acordo com os resultados, concluiu-se que hä ne cessidade do estabelecimento de limites de tolerāncia para a aflatoxina no leite, ausentes na nossa legislação; e pela ne cessidade da atuação da Saūde Pūblica atravēs de inspeção, e atravēs de amplos programas educativos junto aos produtores e industrias. 
SUMMARY

B-type milk sold in the city of São Paulo, Brazil, was examined for Aflatoxin $M_{1}$ and bacterial inhibitors, such as penicilin, hydrogen peroxide, formaldehyde and chlorine.

Samples were taken from the four most consumed brands.

The study was longitudinal, with probabilistic sampling, divided in two equals periods of 140 days each; the total number studied was 224 in each period.

During the first period, June $14^{\text {th }}$ through October, $31^{\text {st }}$, 1982, all mentioned contaminants were studied where as aflatoxin was not studied in the second period, November $7^{\text {st }}$, 1982 through March, $30^{\text {th }}, 1983$, as its occurrence is seasonal and the probability of it being encountered is practically nul 1 .

Aflatoxin, although is small proportion (1.8\%) and at low levels, was present in the four brands studied.

The prevalence of bacterial inhibitors was high is both periods $(4.95 \%$ in the first period and $4.50 \%$ in the second).

During the first period the incidence of penicillin residues and non-identified inhibitors was $0.9 \%$ and $3.6 \%$ respectively, in the first period, and $0.45 \%$ and $3.15 \%$ respectively in the second. 
The proportion of samples containing hidrogen peroxide, formaldehyde was $10 w$ and chlorine was absent in all.

our results show the need for establishing legal tolerance limits for aflatoxin in milk (which has not been done as yet) and the need for Public Health measures regarding inspection and education of productors and industrial plants. 
0 uso de aditivos quĩmicos em alimentos è prātica muito antiga, tendo surgido da necessidade de se conservar as propriedades físicas e organolépticas destes, preservando-os para o consumo humano

Atualmente, na maior parte dos alimentos industria lizados há emprego de aditivos, com a finalidade de mantēlos integros.

Em latícinios, por exemplo, o sal é usado como pre servativo na manteiga e nos queijos; o cloreto de cālcio é empregado como neutralizante no creme.

Apesar da necessidade de aditivos na indústria al $\underline{i}$ mentīcia, o seu emprego é rigorosamente mantido sob controle oficial pela Comissão Nacional de Normas e Padrões para Ali mentos (CNNPA) do Ministério da Saūde, através dos decretos nọ 55.871 de 26 de março de 1965 e o decreto lei de 21 de ou tubro de 1969 .

A regulamentação ${ }^{150}$ do uso de aditivos é feita por "listas positivas", isto é, listas em que aparecem os aditivos, sua função, os alimentos em que podem ser usados e os limites māximos desse uso. A sua utilização está também na dependência de ser tecnologicamente necessārio e de não oferecer riscos à saūde pūblica.

o decreto no 55.871 considera como aditivo para ali- 
mento "toda substāncia intencionalmente adicionada ao mesmo com a finalidade de conservar, intensificar ou modificar suas propriedades, desde que não prejudique seu valor nutritivo".

0 mesmo decreto define ainda, como aditivo inciden ta1: "substāncia residual ou migrada, presente no alimento como decorrēncia das fases de produção, beneficiamento, acon dicionamento, estocagem e transporte do alimento ou das maté rias primas nele empregadas".

De acordo com o Decreto nọ 55.871 , pode-se agrupar os aditivos em duas categorias:

1 - intencional, com a finalidade sempre de trazer melho ria ao alimento;

2 - incidental, aquele que aparece em decorrēncia do tra tamento preliminar do alimento.

0 Decreto Lej nọ 986 não encarou de modo diferente o problema e considera "aditivo intencional toda substāncia ou mistura de substāncias dotadas ou não de valor nutritivo, ajuntada ao alimento com finalidade de impedir alterações, manter, conferir ou intensificar seu aroma, cor e sabor, modificar ou manter seu estado físico geral ou exercer qualquer ação exigida para uma boa tecnologia de fabricação do alimento".

0 mesmo decreto define "aditivo incidental como to da substância residual ou migrada presente no alimento em decorrência dos tratamentos prévios a que tenham sido submetidos a matéria prima alimentar e o alimento "in natura" e do contato do alimento com os artigos e utensilios empregados nas suas diversas fases de fabrico, manipulação, embala- 
gem, estocagem, transporte ou venda..."

Este ültimo conceito ${ }^{150}$ engloba o que hoje é considerado "Contaminante de Alimentos" pela Comissão de Peritos FAO/WHO e que abrange os residuos de pesticidas, as toxi nas e os contaminantes metálicos.

Entretanto, o emprego desses aditivos em alimentos é proibido quando:

1 - houver evidéncia ou suspeita de que o mesmo possui to xicidade atual ou potencial;

2 - interferir sensivel e desfavoravelmente no valor nutritivo do alimento;

3 - servir para encobrir falhas no processamento e nas técnicas de manipulação;

4 - encobrir alteração ou adulteração na matēria prima ou no produto já elaborado;

5 - induzir o consumidor a erro, engano ou confusão.

Pela natureza dos aditivos incidentais e devido aos poucos conhecimentos a respeito, não existe ainda legislação especifica que regulamente a presença destes em alimentos. Por esse motivo a identificação de toda substāncia residual ou migrada presente no alimento se torna indispensável.

Os aditivos incidentais são encontrados, em latic nios e derivados, quando ingeridos pelo animal produtor de leite, através da ração (micotoxinas), do medicamento (antibiōtico) ou de pastagem (resíduos de pesticidas) ${ }^{46}$. Apōs metabolização, estes resíduos são incorporados ao leite. Também, podemos considerar como aditivos incidentais os resí duos de formol e de cloro presentes no leite e derivados mu tas vezes remanescentes da higienização de utensílios e de 
equipamentos.

Apesar da āgua oxigenada não ser considerada aditị vo incidental, pois $\bar{e}$ adicionada ilegalmente ao leite com a finalidade de inibir o crescimento bacteriano, o seu contro le também se faz necessário pelo fato de alterar as propriedades físico-organolēpticas do produto.

Considerando a importāncia do leite na alimentação humana, principalmente na dieta infantil, a presença de contaminantes nesse alimento, por si só representa um problema de Saúde Pública que deve ser cuidadosamente examinado.

\section{$1.1-$ Aflatoxinas}

A presença de fungos nos alimentos além de ocasionar alterações indesejāveis no sabor e na qualidade, limitan do sua aceitação, apresenta a possibilidade de produzir toxi nas.

A relação entre as toxinas microbianas dos alimentos e as enfermidades produzidas no homem e animais baseia-se frequentemente na observação de sintomas apōs ingestão do produto contaminado, o que permite estabelecer uma relação clara entre causa e efeito. Entretanto, no caso das toxinas dos alimentos mofados, esta situação não ē tão evidente; por exemplo, o envenenamento pelo ergot, toxina do centeio, que ocorre esporadicamente desde a antiguidade, somente em 1711 , foi associado ao crescimento do fungo Claviceps purpurea. Em 1875 identificaram-se seus componentes tóxicos 299 .

Entre 1942 e 1947, em certas regiões da Rūssia foi registrada uma forte epidemia de leucopenia tōxica alimentar 
com elevada taxa de mortalidade atribuĩda a contaminação de grãos com fungos do genero Fusarium ${ }^{42}$. Na mesma ēpoca, no Japão também ocorreu um surto epidémico grave por contaminação do arroz com fungos do gênero penicillium 42 .

Em 1960, na Inglaterra a morte de mais de 100.000 peruzinhos e 14.000 patinhos foi relacionada à ingestão de torta de amendoim importadas do Brasil, que haviam sido misturadas à ração. As aves morriam no prazo de uma semana e apresentavam as cēlulas do parēnquima hepātico completamente degeneradas 18,257 .

Simultaneamente, em diferentes paĩses foram registrados episōdios anālogos em vārias espécies animais relacio nando-se à alimentação e, em particular, ao farelo de amendoim $7,45,148,155,156,224$. Diante da grave ameaça à saūde an $\underline{i}$ mal, que o consumo de farelos contaminados representava, foram conduzidos estudos e anālises que resultaram na extração e isolamento de uma substāncia tóxica.

Allcroft e colaboradores ${ }^{3,4}$, verificaram que substâncias isoladas e extraĩdas da farinha contaminada eram tóxicas quando administradas em espécies sensíveis.

Asplin \& Carnaghan ${ }^{18}$ demonstraram que um extrato de farinha de amendoim parcialmente purificado e a farinha de amendoim, quando administrados a patinhos produziam uma pro1 iferação do epitēlio do ducto biliar.

Sargeant e colaboradores 223,224 mostraram que a to xicidade do extrato era causada por compostos tōxicos elaborados por certas cepas de A. flavus, que se desenvolviam na farinha.

Desde então, foi desenvolvido um importante ésforço científico, centralizado no estudo dessa toxina, em virtu de do grave risco que potencialmente podia, tambēm, represen 
TABELA 1 - Exemplos de incidencia de aflatoxina em produtos agrícolas

\begin{tabular}{|c|c|c|}
\hline Produto & Localização & Referēncias \\
\hline Milho & $\begin{array}{l}\text { U.S.A., França, Austrālia, } \\
\text { Yoguslävia, Egito, Argenti } \\
\text { na }\end{array}$ & $\begin{array}{l}21,36,53,102,119,120,146,210, \\
237,238,239,241,242,243,258, \\
262,286 .\end{array}$ \\
\hline Amendoim & $\begin{array}{l}\text { U.S.A., Africa, Indonésia, } \\
\text { India, Tailândia, Brasil, } \\
\text { Argentina, Egito. }\end{array}$ & $\begin{array}{l}37,82,83,89,118,122,138,139, \\
153,210,287,\end{array}$ \\
\hline $\begin{array}{l}\text { Caroço de } \\
\text { algodão }\end{array}$ & $\begin{array}{l}\text { U.S.A., América Central, } \\
\text { India, Sudão }\end{array}$ & $73,94,140,217,226$ \\
\hline Copra & India, Ceilão & $17,25,139$ \\
\hline Centeio & França & 146 \\
\hline $\begin{array}{l}\text { Aveia, Sorgo, } \\
\text { Trigo }\end{array}$ & França, U.S.A., Aus trālia & $36,146,228,240,244,246$ \\
\hline Cevada & $\begin{array}{l}\text { França, Grã-Bretanha, Aus } \\
\text { trālia }\end{array}$ & $36,146,246$ \\
\hline Soja & $\begin{array}{l}\text { U.S.A., França, Alemanha, } \\
\text { Egi to }\end{array}$ & $17,26,70,131,210,237,241,245$ \\
\hline Arroz & $\begin{array}{l}\text { U.S.A., Vietña do Sul, } \\
\text { Asia. }\end{array}$ & $101,146,157,228,235,237$ \\
\hline Linhaça & U.S.A., Alemanha & 16 \\
\hline Alfafa & Canadā, Brasiı & 184 \\
\hline Cacau & França, Suiça & 146 \\
\hline Girassol & Itālia, França. & 138 \\
\hline Trigo & U.S.A., Brasi1, Egito & $101,201,209,228,240,244,245$ \\
\hline Ração & $\begin{array}{l}\text { U.S.A., Canadā, Polōnia, } \\
\text { Grã-Bretanha, Austrālia, } \\
\text { Brasil, Tunisia }\end{array}$ & $\begin{array}{l}1,20,32,37,82,203,218,231, \\
246,254,268 .\end{array}$ \\
\hline Feijão & Brasil & 220 \\
\hline
\end{tabular}


tar à saūde humana. A micotoxina isolada e identificada foi denominada aflatoxina. As aflatoxinas tem se mostrado carci nogēnicas, sendo produzidas por vārias espécies de fungos do gēnero Arpergillus ${ }^{124,230}$. São encóntrados naturalmente em um grande nūmero de produtos agrícolas em todas as zonas do mundo. Além disso, muitos desses produtos são utiliza dos como ingredientes de rações. Alguns exemplos de incidēn cia de aflatoxina em produtos agrícolas estão indicados na Tabela 1 .

As aflatoxinas também jā foram detectadas em ovos, leite, produtos lácteos, carne e derivados e alimentos industrializados $13,31,38,83,88,93,97,129,140,145,151,154,162$, $206,221,260,267,269,310$.

A contaminação desses alimentos por aflatoxina pode ser causada diretamente através do crescimento de fungos toxicogénicos em produtos agrícolas ou indiretamente através de resíduos derivados do metabolismo $11,14,34,61,87,99,117$, $126,293,298$.

Na famîlia das aflatoxinas são conhecidos mais de doze compostos; entre eles, somente aflatoxinas $B_{1}$ e $M_{1}$ apre sentam interesse à saūde pūblica pelas seguintes razões:

a - a aflatoxina $B_{1}$ por aparecer em maior teor, cerca de $80 \%$ das aflatoxinas e, também, por ser a mais potente em termos de toxicidade aguda, mutagenicidade e carcinogenicidade; esta toxina ao ser metabolizada pe 10 tecido animal produz seis metabōlitos $224,293,307$.

b - a aflatoxina $M_{1}$, um dos seis metabōlitos da $B_{1}$, entre eles o mais tóxico e por ser encontrado invariavelmente no tecido animal, excretas, no leite e der $\underline{\mathbf{i}}$ vados; a conversão em aflatoxina $M_{1}$ ocorre no fígado, 
produzida pela hidroxilação do quarto carbono da mo 1écula de aflatoxina $B, 15,43$.

o primeiro resíduo de aflatoxina observado no teci do de vacas e o mais intensamente estudado foi a aflatoxina $M_{1}$ no leite $18,104,168$. Muitos estudos foram realizados com a finalidade de determinar a relação entre a ingestão e a excreção desta aflatoxina. Nesses estudos concluiu-se que o teor de aflatoxina $M_{1}$ excretada no leite é diretamente proporcional a quantidade de aflatoxina $B_{1}$ ingerida. Também fi cou evidenciado que a aflatoxina aparece quando o conteüdo de aflatoxina $B_{1}$ na ração for superior a $46 \mathrm{ppb} 5,8,147,169,185$, 195,199

A relação entre o teor de aflatoxina $B_{1}$ administra da e a quantidade da M produzida no leite pode depender da via de administracão e da espécie de animal que estā sendo estudada 15,70 . Kiermeir ${ }^{127}$ demonstrou que no leite de vaca quando quantidades significativas são consumidas, a aflatoxina aparece 12 horas apōs a alimentação, tempo necessārio, tambēm, para a formação do prōprio leite. Admite-se atualmente que a quantidade de aflatoxina $M_{1}$ excretada pela vaca varia de 1 a $3 \%$ da dose da $B_{1}$ ingerida. Esta estimativa está baseada nos resultados experimentais obtidos após a administração por um período $1 \mathrm{imitado,} \mathrm{de} \mathrm{alimento} \mathrm{fortemente} \mathrm{con}$ taminado $4,6,130,147,168,169,176,183,195,199$.

0 teor de aflatoxina $M_{1}$ no leite tem mostrado sofrer uma influēncia sazona $7^{255,278,285}$. Fremy e colabora dores $^{86}$ verificaram, na França, que as anālises efetuadas no leite, durante o inverno apresentam uma proporção mais eleva da de aflatoxina, e consequentemente, mais mensurāvel do que no verão. Durante o período de primavera e do verão, quando o animal se encontra mais nos campos, o grau de contamina 
ção do leite fica bastante reduzido em relação ao perído de es tabulação.

Na Bēlgica 285 foi constatado que no leite proveniente de grandes produtores havia major incidéncia de aflatoxina do que naquele produzido em pequenas propriedades; a origem desta diferença mostrou ser decorrente do fato de que na exploração intensiva do gado em regiões de grande produção leiteira, exige-se grandes quantidades de alimentos, havendo necessidade de armazenamento ao ar livre propiciando condições adequadas ao crescimento de fungos. Tambēm a variação regional da contaminação do leite, estā relacionada com o uso de rações concentradas.

A qualidade e a procedencia da fração é um fator importante na contaminação dos produtos lácteos. Por isso tem-se enfatizado sobre a importāncia de se estabelecer bons métodos de colheita, tratamento, transporte e distribuição, a fim de impedir o crescimento de fungos e consequentemente a produção de micotoxina $57,95,198,255,278$.

Geralmente, 3 a 5 dias apōs a remoção da ração con taminada, a aflatoxina $M_{1}$ não é mais detectada no leite 6,15 , $130,160,199$

As aflatoxinas podem apresentar dois niveis de toxicidade: a aguda provocando a morte de animais por meio de rações fortemente contaminadas, e a crōnica com efeito carci nogēnico, mais frequente no homem, ocasionada pela ingestão direta de micotoxinas presentes no alimento ou pela contaminação secundāria atravēs do consumo de resîduos derivados do me tabolismo anima $9,10,40,65,69,99,117,152,299$.

Espécies de animais domésticos como boi, cão, porco, peru, galinha e animais de laboratörio, consumindo quantidade sub-letal de aflatoxinas por vārios dias, desenvolve- 
ram uma sīndrome tóxica, com danos no fígado $39,41,49,71,189$, $194,215,222,250$. As quantidades tóxicas acumuladas variam de 0,3 a 15 p.p.m. 70 .

0 primeiro sintoma clinico de aflatoxicoses crônicas, em mamíferos, geralmente manifesta-se pela falta de ape tite, redução do crescimento e perda de peso $4,68,151,156,160$. observações patolōgicas revelaram icterícia generalizada e cirrose do fígado com proliferação das cēlulas do ducto bili ar e fibrose peritonial 39,188 .

Embora em menor extensão do que nos animais, a literatura tem apontado casos de aflatoxicoses agudas em humanos. Por exemplo, na India ${ }^{136}$, altos niveis de aflatoxinas em grãos de milho ocasionaram hemorragia gastro intestinal, principalmente em crianças.

A incidencia de aflatoxina $M_{1}$ no leite e derivados em determinadas regiões, tem representado um perigo para a saúde, especialmente de recēm-nascidos e crianças que consomem mais o produto e portanto, são expostos a um risco maior quanto aos efeitos adversos dessa toxina 211.

Não hā evidéncia de que a aflatoxina $M_{1}$ seja carcị nogênica ou mutagênica como, a aflatoxina $B_{1}$. Entretanto, apresenta grande toxicidade, dependendo da dose pode causar necrose no fígado70,201,205. Várias experiēncias foram realizadas sobre a toxicidade da aflatoxina $M_{1}$ em diferentes espécies animais, como na truta, porco, rato e vaca44,187,248, $249,276,281,306,308$.

Na fabricação de derivados de leite, o desnatamento tem mostrado afetar a distribuição de aflatoxina $M_{1}$ no pro duto final. Como ela fica associada à caseina, durante o desnatamento do leite integral, $84 \%$ do total do conteūdo de aflatoxina $M_{1}$ fica retido no produto desnatado 90,270 . 
No processo de pasteurização, o efeito do aquecimento na estabilidade da aflatoxina $M_{1}$ foi estudado, mas os resultados foram conflitantes. Värios autores admitem que a pasteurização não afeta a sua estabilidade 4,261,283,284, $300,301,302,303$. Entretanto, outros consideram que cerca de $80 \%$ da aflatoxina é destruída durante a pasteurização 85 , $128,173,208$.

Inspeções em outros países constataram a presença de altos níveis de aflatoxina $M_{1}$ no leite.

Na Africa do Sul, Purchase e Vorster ${ }^{207}$, em 21 amostras de leite cru analisadas encotraram $23,8 \%$ com aflato xina. Na Holanda, Schuller e colaboradores 229 em 95 amostras de leite pasteurizado, colhidas no período de dezembro de 1972 a abril de 1973 obtiveram 5 amostras positivas para afla toxina. No Irã, em 96 amostras de leite cru analisadas entre 1973 e 1974, Suzangar e colaboradores 271 detectaram 38 amostras com aflatoxina $(39,6 \%)$. Nos U.S.A., em 1975, Paul e colaboradores 211 analisaram 81 amostras de leite crue encontraram $6,2 \%$ positivas. Em 1977, nos U.S.A., houve uma grande incidéncia de aflatoxina em alimentos; em pesquisa rea lizada em 4 estados, $\operatorname{Cobb}^{50}$, constatou que em 302 amostras de leite 19 excederam o limite de 0,5 ppb (limite estipulado pelo F.D.A.). Em 1975, na Bēlgica, Van Pēe 285 encontrou em 68 amostras de leite pasteurizado, $61,7 \%$ com aflatoxina. Na Tchecoslovāquia, Bartŏs e Matyăš23,24 em 1978, analisando 70 amostras de leite pasteurizado, e em 1981, 77 amostras de lei te cru, encontram respectivamente 25 e 5 amostras positivas. Em 1981, na França, Fremy e colaboradores ${ }^{86}$ constataram major prevaléncia de aflatoxina no inverno (45\%) do que no verão $(25 \%)$.

No Brasil, em 1975, Pozzobon e colaboradores 202 em 
pesquisa realizada na cidade de Santa Maria no Rio Grande do Sul, jā haviam constatado a presença de pequenas quantidadès de aflatoxina $M_{1}(2 \%)$ em 50 amostras de leite cru comerciali zado. Entretanto essas amostras não foram probabilisticas, não havendo preocupação quanto a procedéncia do leite. A baixa incidéncia na ocasião fora atribuida à armazenagem ade quada da ração, que teria evitado a presença de aflatoxina.

Sabino 219 , em São Paulo, recentemente analisou 100 amostras de leite pasteurizado de 9 marcas comercializadas no estado. Essas amostras foram coletadas no periodo de julho de 1979 a setembro de 1981, detectando-se aflatoxina em somente uma delas. o objetivo principal desses trabalhos foi a padronização de método de anălise para detecção de aflatoxina, e por isso, a amostragem não foi probabilística. Esses valores foram justificados pelo autor como sendo consequéncia do fato que as usinas recebem leite de diferentes procedéncias, havendo portanto uma mistura de leite com e sem toxina, ocasionando a diluição destas, impossibilitando a sua detecção.

Na maioria dos países a legislação sobre alimentos e rações proibe a venda de produtos contaminados por substān cias venenosas ou nocivas. Entretanto, poucos dispõem de re gulamentos, e quando os possuem são incompletos, estabelecen do os limites admissiveis de aflatoxinas nos alimentos. As legislações que abrangem o controle dessa micotoxina limitam- se na maioria das vezes, a certos produtos facilmente con tamināveis, como óleos de sementes e derivados.

$$
\text { 0 F.D.A. } 80,81,259 \text { elaborou vārias especificações a }
$$

respeito. Os niveis permissiveis constam da Tabela 2 . 
TABELA 2 - Limites de tolerāncia para aflatoxina estabeleci dos pelo F.D.A.

Alimento

Nivel $(\mu \mathrm{g} / \mathrm{kg})$

Nozes brasileiras

20

Alimentos e rações

20

Leite

0,5

Amendoim e derivados

20

Nozes verdes

20

Fonte: Labuza, T.P. - Regulation of mycotoxins in foods. J. Food Prot., $46: 260-5,1983^{142}$.

Na Tabela 3 , estäo reunidos os paises cuja legisla ção apresenta regulamentação para a aflatoxina: Japão, Malásia, Polónia, Suécia, U.S.A., incluem todos os alimentos em seu controle; Canadá, Dinamarca, Itālia, Malawi, Noruega, Repūblica Federal Alemã, Reino Unido e Rodēsia somente incluem poucos produtos facilmente contamināveis; enquanto que a India estabeleceu limites de toleráncia somente para produtos de exportação; a Bēlgica, França e Israel ape nas para rações.

A legislação brasileira ${ }^{56}$ (Res. $34 / 76$ da antiga (NNPA) estabeleceu para alimentos o 1 imite de $30 \mu \mathrm{g} / \mathrm{Kg}$ para as aflatoxinas calculadas pelas somas dos conteūdos das afla toxinas $B_{1}$ e $G_{1}$; não existindo legislação especifica para o leite. 
TABELA 3 - Limites de tolerāncia para aflatoxinas em alimentos e rações.

\begin{tabular}{|c|c|c|}
\hline Pais & $\mu \mathrm{g} / \mathrm{kg}$ & Produto \\
\hline Japão & 10 & todos \\
\hline Malāsia & 0 & todos \\
\hline Polónia & 5 & todos \\
\hline Suécia & $5-10$ & todos \\
\hline U.S.A. & $15-20$ & todos \\
\hline Canadā & 15 & amendoim e derivados \\
\hline Dinamarca & $5-10$ & amendoim e derivados \\
\hline Hol anda & 5 & amendoim e derivados \\
\hline It $\operatorname{a} l$ ia & 50 & amendoim e derivados \\
\hline Malawi & 5 & amendoim e derivados \\
\hline Noruega & 600 & amendoim e derivados \\
\hline \multirow[t]{2}{*}{ Rodésia } & 25 & amendoim e derivados \\
\hline & $50-400$ & ração \\
\hline $\begin{array}{l}\text { Repūblica Federal } \\
\text { Alemã }\end{array}$ & $5-10$ & frutos secos \\
\hline Reino Unido & 50 & amendoim e derivados \\
\hline India & 30 & $\begin{array}{l}\text { amendoim e derivados } \\
\text { (exportação) }\end{array}$ \\
\hline Bélgica & 50 & ração \\
\hline França & 50 & ração \\
\hline Israel & 20 & ração \\
\hline
\end{tabular}

FONTE: KROGH, P. - Mycotoxim tolerances in foodstuffs. Ann. Nutr. Alim., 31: 411-4, 1977. Adaptação dó original 137 . 


\section{2 - Antibiōticos}

A contaminação de alimentos por substāncias empregadas nas práticas agropecuārias representa indiscutivelmente, sério problema de saūde püblica, por ser uma das formas mais comuns de poluição alimentar. Entre os poluentes desta categoria, pelo largo e indiscriminado uso em medicina veterināria, situam-se os antibióticos.

A penicilina foi o primeiro antibiótico no combate da mastite. Mais tarde outros antibióticos foram emprega dos: estreptomicina, clorotetraciclina, oxitetraciclina, bacitracina, neomicina, subtilina e cloranfenicol2,19,67,121, $164,165,166,172,198,251,289$. Atualmente existe no comércio um grande nūmero de preparações com antibiōticos destinados ao combate da mastite. Recentemente, foram identificados 54 produtos para aplicação intramamāria contendo 20 diferentes substâncias antimicrobjanas 30 .

No Brasil os antibiōticos são de venda livre, e am plamente empregados pelos criadores, o que deve provocar con taminação, principalmente do leite e das carnes de aves.

A presença nos produtos 1 ācteos resulta, principal mente, do uso terapéutico de antibiōticos em casos de mastites e nas carnes de aves por serem componentes normais das chamadas rações balanceadas $133,266,297,309$.

No caso da mastite, por causar grande diminuição na produção leiteira, uma queda de 5 a $94 \%$, generalizou-se o em prego de antibiōticos no seu tratamento $78,91,149,192,198$. Mui tas vezes a ignorāncia do produtor sobre os problemas que o antibiōtico pode causar, faz com que se utilize o leite dos animais em tratamento, misturando-o com aquele produzido pe 
los animais sadios.

No Brasil, ao contrārio de outros países, o empre go de penicilinas no tratamento de mastite não é tão intenso, pois, as espécies e as frequências dos agentes etiolōgi cos costumam variar conforme a região, as condições de cria ção, etc. $92,105,141,143,144,171$. Sua presença também é pequena nas associações de antibiōticos, atualmente utiliza das em medicina veterināria. Ela é mais empregada no tratamento de infecções por via sistêmica.

Segundo Marth \& Ellickson ${ }^{166}$, a quantidade de antibiōtico utilizada numa aplicação individual, por úbere varia de acordo com:

1 - a espécie de antibiótico utilizada;

2 - a gravidade da infecção;

3 - a frequéncia com a qual o antibiōtico é administrado;

4 - o critério da pessoa que está administrando o antibiōtico.

Apōs a aplicação no übere, somente uma parte vai ser absorvida, e incorporada ao leite, a qual pode variar in - dividualmente de vaca para vaca, estando sujeito a uma série de fatores $2,29,35,72,75,79,100.163,180,225,279$, como:

1 - concentração e espécie de antibiótico utilizado;

2 - veículo empregado no medicamento;

3 - quantidade de leite excretado;

4 - intervalo de tempo entre o tratamento e a ordenha.

Os antibióticos administrados parenteralmente for necem um modesto pico $\left(<10^{-1} \mu \mathrm{g} / \mathrm{ml}\right)$ de concentração no: 1ejte. Entretanto a aplicação intramamāria de uma suspensão de antibiōticos diretamente no quarto ou nos quartos infectados 
do ūbere ē a via preferida para tratamento de mastites por causa da alta concentração local $\left(>10^{-3} \mathrm{\mu g} / \mathrm{ml}\right)$ que pode alcançar na glāndula mamāria 304.

os estudos realizados pelo Food and Drug Adminis tration (FDA) ${ }^{2}$ em 1953, mostraram que depois de uma aplicação intramamāria com 100.000 unidades de penicilina, o nível do antibiōtico na primeira e segunda ordenha foi de $8,15 \mu \mathrm{g} / \mathrm{ml}$, para a quinta e sexta ordenha $0,042 \mu \mathrm{g} / \mathrm{ml}$, e nada mais foi detectado nas ordenhas subsequentes; após este estudo estabe leceu-se que o leite produzido nos trēs dias seguintes ao tra tamento (72 horas) não deve ser consumido.

outros autores também confirmaram resultados encon trados pelo FDA, que quando uma dose moderada de penicilina é administrada haverá persistēncia de resíduos de antibióticos até 72 horas apōs o tratamento $84,134,172,273,282$. A maior concentração de penicilina excretada ocorre nas primeiras 24 horas apōs o tratamento, principalmente na primeira ordenha, onde são excretados cerca de $17,6 \%$ da dose administrada 198 . Entretanto, ao se empregar altas concentrações de penicilina resulta um longo perīodo de eliminação, ultrapassando o tem po previsto (72 horas) pela legislação em vigor $12,116,197,204$, $252,253,280$.

Em geral, a estreptomicina é encontrada no leite até 72 horas apōs o tratamento ${ }^{2,168,198 . ~ A ~ c l o r t e t r a c i c l i n a ~ e ~ a ~}$ oxitetraciclina apresentam um tempo variāvel de permanēncia podendo em casos de doses maiores persistirem até 5 dias no le ite $121,172,198$.

Os antibiōticos mais utilizados no combate à masti te como clortetraciclina, cloranfenicol, estreptomiciná, oxi tetraciclina, neomicina e penicilina são todos termo-resis tentes; as operações industriais como pasteurização, evapora 
ção, secagem, etc., pouco afetam suas estabilidades 125,233 , 234. Conforme a natureza do antibiōtico as diferentes frações do leite contém maior ou menor quantidade de resíduos. Na nata, por exemplo, o cloranfenicol e a tetraciclina concentram-se em maior grau do que a penicilina e estreptomicina $166,247,312$.

A presença de antibiōticos no leite tem criado sērios problemas para a saūde pūblica e para a indūstria de laticinios. Os riscos para a saúde associado ao consumo de produtos contaminados com antibiōticos incluem:

1 - respostas alérgicas - A presença de penicilina no leite, pode ocasionar hipersensibilidade ao consumidor, em alguns casos até dermatite alérgica $74,288,311$;

2 - mudanças na função intestinal. Pode ocorrer alteração da flora intestinal do consumidor, reduzindo a sintese de vitaminas no trato intestina1 264,265 ;

3 - desenvolvimento de bactéria patogénica resistente, devido a formação de estirpes bacterianas resisten tes aos antibiōticos; resistēncia, aliàs que assume papel relevante após a comprovação de sua transferēn cia extracromossomal para outras bactérias, em parti cular as entéricas, nas quais esse fenōmeno é mais frequente 265,294 .

Os antibiōticos tambēm provocam alterações nas pro priedades organolēpticas e tecnológicas dos produtos läcteos industrializados. Entre os principais problemas, podemos des tacar:

1 - influéncia no maduramento natural do queijo durante a sua fabricação $66,98,108,109,112,134,167,170,272,305$; 
2 - retardamento na produção de ācido lātico e alteração no sabor dos derivados fermentados $28,52,96,106,135$, 191,214

3 - inibição do crescimento de culturas de "starter"114, $123,124,186,232,236,263$;

4 - interferéncia na interpretação dos resultados de a guns testes de controle de qualidade 48,103,107,115, 167

Possivelmente o primeiro levantamento sobre a presença de resíduos de antibiōticos no leite tenha sido realizado em 1951, 131 no estado de New York, U.S.A.. Foram analisadas 1794 amostras de leite fresco e pasteurizado provenien tes de 36 cidades. Das amostras analisadas, $6 \%$ continham pen cilina na proporção de $0,05-0,1 \mu \mathrm{g} / \mathrm{ml}$ de leite. Com o mes mo objetivo em 1954, 1955, 1956 e 1959, foram realizados levantamento pelo FDA 113,165,295,296. Paralelamente às pesqui sas, foi desenvolvida uma campanha educativa entre os produ tores, o que resultou em decréscimo no indice de contamina ção do leite.

Posteriormente, em värios países foram realizadas pesquisas sobre a incidēncia de antibiōticos no leite. Welch ${ }^{295}$, no ano de 1950, em 474 amostras de leite cru e pasteurizado, provenientes de 16 estados dos U.S.A., encontrou penicilina em $11,6 \%$. Na Äfrica do Sul, em 1959, Meara ${ }^{174}$ encontrou res pectivamente $5,37 \%$ e $3,09 \%$ de inibidores e de penicilina em 1.229 amostras de leite analisadas. Kosikowski 132 , no estado de New York (U.S.A.) durante o período de novembro de 1959 a março de 1960, encontrou proporção elevada de antibiótico no leite. Aproximadamente 10.000 amostras de leite provenientes de 4.000 produtores foram analisadas. Concomitantemen 
te foi conduzido um programa educativo junto aos produtores, que resultou numa queda da incidéncia de $6,5 \%$ para $0,45 \%$. $0^{\prime R e i l l e y^{193}}$ em 1970 , pesquisando 1.765 amostras de leite cru e 174 amostras de leite pasteurizado na cidade de Dublin (Irlanda), constatou a presença de inibidores em indices de $8,2 \%$ e $5,7 \%$ respectivamente. A presença de penicilina foi verificada em $5,8 \%$ e $4,6 \%$ das amostras analisadas. Cook e colaboradores 60 , em 1976 , encontraram $3,2 \%$ de penicilina em 366 amostras de leite pasteurizado, comercializado na cidade de Johannesburg (Africa do Sul). Na Espanha, no ano de 1977, Polo Lara200, em 1.000 amostras de leite cru, encontrou $1,19 \%$ com penicilina e 9,3\% com kanamicina.

No Brasil, na cidade de Belo Horizonte, em 1963, Reis e colaboradores 212 , abordaram o problema de antibióticos no leite. Em um total de 2.079 amostras de leite cru exa minadas, foram encontrados $1,44 \%$ positivas para penicilina e $0,58 \%$ positivas para substâncias inibidoras indeterminadas. Em 1960, Mel10 Filho e colaboradores ${ }^{178}$. encontraram penicilina em $1,9 \%$ em 1.000 amostras analisadas de 1 eite tipo "C" comercializado em São Paulo.

Em Niterōi, em 1976, Tavares de Macedo e colabo radores ${ }^{161}$ em 136 amostras de leite cru detectaram 5,8\% com resĩduos de antibiōticos.

Meller e colaboradores ${ }^{175}$, em 1974, em Santa Maria (RS) constataram a presença de penicilina em $1 \%$ das 100 amos tras de leite cru analisadas.

Em 1978, em Belo Horizonte, Fagundes e colabora dores $^{76}$, verificaram que a prevaléncia de antibiōticos no leite tipo "B" foi de 5,49\%, enquanto no leite tipo "Ć", foi de $1,25 \%$.

A major incidēncia de antibiōticos no leite tipo 
"B" parece estar relacionada com as condições de criação e tratamento do gado. A estabulação e a utilização da ordenha mecānica são fatores preponderantes para a formação de masti te ${ }^{51}$. 0 ambiente estando contaminado, e as vias de transmis são presentes, facilmente haverā infecção do ūbere, teta e mama $64,213,216$.

As principais fontes de infecções costumam ser:
a) vacas doentes 47,51
b) teta suja internamente e externamente 27
c) tratador 61
d) corpos estranhos 27
e) fezes e palha33,141
f) vacas doentes provocam diarréia nos bezerros, aumen - tando a contaminação do estábu10 47,51
g) serragem para cama 213

Segundo regulamento do F.D.A. de 1953, a presença de residuos de antibióticos no leite e seus derivados consti tui adulteração.

No Brasil, somente a partir de 1980, surgiu uma le gislação para o leite ${ }^{181}$, permitindo sua comercialização somente apōs 72 horas, a partir da ūitima aplicação de antibiō ticos, independentemente da via de inoculação. Entretanto, não se tomou nenhuma medida quanto à fiscalização junto ao produtor, tendo em vista a constatação da aplicação da lei.

1.3 - Agua 0xigenada, Cloro e Formol

A Organização Mundial de Saūde (OMS) tem repetidamente feito recomendações, estabelecendo normas de utilização 
de aditivos em geral e sugerindo medidas prāticas, aos gover nos e autoridades competentes, a serem adotadas na tecnologia alimentar e na prática da medicina veterināria.

Há longos anos a técnica industrial vem estudando a possibilidade da obtenção do meio conservante ideal e capaz, pelo seu emprego, de suprimir operações onerosas e espe cializadas.

Entretanto, a maioria dos conservantes químicos e bioquîmicos tem-se mostrado tóxico ou sensibilizante para o consumidor e de ação conservante limitada. No caso do leite tais aditivos alteram muitas vezes as suas propriedades orga nolēpticas e sua composição, podendo prejudicar também a industrialização dos seus sub-produtos fermentados. Fato grave a salientar é que tais aditivos não destroem as toxinas bacterianas e certos tipos de microrganismos patogénicos 177 .

Os conservantes no leite se distribuem em duas categorias principais: os que agem como neutralizantes e os que agem como antissépticos. Os neutralizantes atuam sobre o ācido lātico derivadó da bioatividade das bactérias sobre a lactose, não reduzindo a flora microbiana, mas apenas evitando a coagulação do leite. Os conservantes antissépticos geralmente mostram relativo grau de toxidez, modificam profundamente as propriedades do leite. Entre os antissēpticos, os mais conhecidos estão o formol, o cloro e a āgua oxigena da, todos proibidos por lei.

0 formol, na concentração de $1 / 1.000$ ou $1 / 2.000$, pro duz nas primeiras 24 horas, um rāpido decréscimo da flora bac teriana; apōs esse período ocorre uma lenta mas contante diminuição desta e, no fim de 5 dias, o leite estará estéril. $\mathrm{Na}$ proporção de $1 / 20.000$ o formol conserva o leite duas ou três vezes melhor que o mesmo sem tratamento algum, e na con 
centração de $1 / 5.000$ ou $1 / 10.000$ é realmente um bom conservante se não fosse o prejuĩzo que traz para a digestibilidade do produto devido a insolubilidade que provoca na case $n a^{177}$.

Quanto ao cloro, amplamente utilizado no saneamen to da āgua de consumo nas cidades, no leite o seu indice de aproveitamento mostrou ser muito baixo, devido as grandes alterações que produz no gosto e aroma do produto, mesmo em concentrações de 50 a 100 p.p.m.; sabe-se que em concentrações menores a sua ação bacteriana no leite é bem pequena ${ }^{177}$.

Algumas vezes o formol e o cloro, presentes no leite, podem ser remanescentes da higienização dos equipamentos e utensilios utilizados na produção e beneficiamento.

Entretanto, na fabricação dos derivados fermentados como iogurte, coalhada e outros, as substāncias inibido ras inclusive a āgua oxigenada, interferem nas suas qualidades organolépticas.

o perōxido de hidrogēnio, amplamente conhecido em nosso pais, pela maioria dos produtores de leite, como conser vante efetivo sob o nome de āgua oxigenada, foi empregado des de os fins do século passado por Budder ${ }^{177}$, na Alemanha, no processo conhecido como Budderização do leite.

A redução microbiana obtida no uso da $\mathrm{H}_{2} \mathrm{O}_{2} \overrightarrow{\mathrm{e}}$ da ordem de $50 \%$ ou mais, com ligeiro acréscimo de um sabor metá lico ou maltado ao produto. O desaparecimento espontāneo do conservante decomposto pelas diastases libera oxigénio nascente 179 .

A āgua oxigenada altera consideravelmente o teor em vitamina $C$, destruindo cerca de 70 a $90 \%$ de sua quantidade no leite, fato nocivo mesmo em se tratando de um alimento que não é fonte significativa desta vitamina. Afeta a vi 
tamina $B_{1}$ e não hã estudos conclusivos em relação à ação que provoca sobre as vitaminas lipossolúveis 176 .

Ressalte-se, tambēm, entre outros inconvenientes, que o emprego de àgua oxigenada como conservante em laticínios, se aplicado sistematicamente, poderá incitar os produtores a abandonar os esforços para melhorar as condições higiénicas de obtenção de tratamento e transporte do produto. Talvez por esse motivo não seja permitido o seu emprego, apesar de värios autores defenderem o seu uso como conservante para - leite, nos países de clima quente e tecnicamente pouco desenvolvidos, sem condições de transporte rāpido, e capacida de de resfriamento eficaz $54,55,158,159,274$.

Me110 Fitho e colaboradores 178,179 , em 1966 e 1968 constataram, no leite "tipo " $C$ " e no leite em pó consumidos na cidade de São Paulo a presença de $9 \%$ e de $3,5 \%$ de inibidores. Os mesmos autores 177 , em 1969, detectaram a presença de inibidores bacterianos, respectivamente, no nível de $8 \%$ e de $11 \%$, nas amostras analisadas de leite tipo "C" $e$ "B".

Recentemente; em 1981, Barros ¿Perches 22 , encon traram uma alta porcentagem de inibidores no leite distri buido ao consumo da Grande São Paulo, no produto recebido em latões nas plataformas dos postos de resfriamento e usinas de beneficiamento, e naquele resfriado e transportado nos carros tanques e no pasteurizado constataram, respectivamente, $1,50 \%, 21,25 \%$ e $21,87 \%$ de inibidores.

No Brasil, embora não especifique nomes de conservadores e inibidores, a Secretaria de Inspeção de Produtos An mal, proibe a presença destes no leite destinado à alimentação humana, podendo somente ser utilizado na fabricação de sabão ou caseina industrial 62,182 .

o Comité Misto da Organização das Nações Unidas, 
para a Alimentação e a Agricultura e da Organização Mundial da Saūde, discutiu a utilização de āgua oxigenada para conservação do leite, admite o seu emprego somente em casos de situações adversas, como a falta de instalaçōes de refrigera ção para manter a qualidade do leite cru 58 .

Do ponto de vista de saúde pública, o problema dos resíduos no leite, quer a origem destes seja um medicamento veterinārio, um aditivo ou um contaminante administrado dire tamente ao animal ou via alimentação (deliberadamente ou por contaminação das matérias primas), requer estudos tendo em vista o fornecimento de subsidios quer seja para o aperfeiçoamento da legislação sobre o assunto, quer seja para adoção de medidas preventivas e de fiscalização.

0 estudo global dos resíduos de aditivos e de subs tāncias medicamentosas utilizadas em animais domésticos, abrange mültiplos aspectos, o que torna necessário estudos so bre suas implicações e riscos potenciais para a saūde pübli$c a^{292}$. Por exemplo, a administração de uma determinada droga pode levar a formação de diferentes tipos de resíduos que as vezes se diferenciam por sua estrutura química e/ou por suas propriedades farmacológicas, fixando-se nos tecidos dos animais tratados 291 . Nestes, a toxicidade poderā ser mantida, modificada ou aumentada em relação ao princípio ativo original. Por exemplo, um resíduo correspondente a uma entida de química definida, pode se transformar no organismo animal em vārias formas (1ivre, ligada as proteinas, etc.) que pode rão ter diferentes biodisponibilidades e toxicidades para o consumidor que os ingere 77 . Alguns desses resíduos são dificilmente detectāveis mesmo com os métodos analíticos mais aperfeiçoados.

A legislação brasileira tendo em vista o controle de qualidade do lejte estabeleceu normas relativas à adulte- 
ração e à contaminação microbiológica. o controle implica na determinação de padrões higiénicos sanitārios. Os primeiros testes são executados logo na recepção onde se detectam as adulterações, que possam alterar as propriedades organolépti cas. Posteriormente analisa-se a carga bacteriana em virtude da possibilidade do leite difundir patogénicos do rebanho, ou do meio ambiente para o homem.

Entretanto, a legislação é incompleta quanto à detecção da presença dos contaminantes citados quer seja junto ao produtor, quer seja junto às indūstrias.

os resultados de outros países e os estudos precá rios existentes entre nōs, motivou o presente trabalho, que procurou mostrar por meio de uma amostragem probabilistica, - risco pelo consumo desses contaminantes por populações do Estado de São Paulo. 
2 - OBJETIVO

Com base nos fatos verificados no capitulo anteri or, o presente trabalho tem como objetivo:

a - anālise das coṇdições do leite tipo "B" comercializa do em São Paulo, em relação à presença de aflatoxi na ;

b - detecção da presença de outros contaminantes, como antibiōticos, àgua oxigenada, formol e cloro. 


\section{3 - MATERIAL E METODOS}

\section{1 - Amostragem}

As amostras de leite tipo "B" utilizadas na presen te pesquisa foram provenientes das quatro marcas de maior consumo pela população de São Paulo.

0 trabalho constituiu-se em um estudo longitudinal dividido em dois períodos iguais de 140 dias. No primeiro pe ríodo, de 14 de junho a 31 de outubro de 1982 , foram pesquisados todos os contaminantes propostos. Como a aflatoxina sofre influência sazonal, por isso era maior a possibilidade de ser encontrada nos meses de temperaturas mais baixas, no segundo período, de 01 de novembro de 1982 a 30 de março de 1983, esta não foi pesquisada.

Em cada período de 140 dias, houve 20 segundas-fe ras, 20 terças-feiras, etc., de tal forma que cada dia da se mana foi repetido 20 vezes (Figura 1 e 2 ).

A unidade amostral foi o conglomerado constituído pe la totalidade dos sacos de leite produzido em um dia, em cada usina. Cada saco de leite foi representativo da produção diäria por ser o leite homogeneizado antes de seu envasamen to. Assim, cada usina apresentou 140 conglomerados neste pe rĩodo; as 4 usinas formaram 560 conglomerados que correspondem ao universo da pesquisa. 
FIGURA 1 - Plano de amostragem - Relação dos dias correspondentes ao 10 período.

\begin{tabular}{|c|c|c|c|c|c|c|c|c|}
\hline Mês & $\begin{array}{c}\text { Ordem } \\
\text { da } \\
\text { Semana }\end{array}$ & $\begin{array}{r}2 \mathrm{a} . \\
\text { feira }\end{array}$ & $\begin{array}{r}3 a . \\
\text { feira }\end{array}$ & $\begin{array}{r}4 a \\
\text { feira }\end{array}$ & $\begin{array}{r}5 a \\
\text { feira }\end{array}$ & $\begin{array}{c}6 a . \\
\text { feira }\end{array}$ & Säbado & Domingo \\
\hline \multirow{3}{*}{ Junho } & 1 & 14 & 15 & 16 & 17 & 18 & 19 & 20 \\
\hline & 2 & 21 & 22 & 23 & 24 & 25 & 26 & 27 \\
\hline & 3 & 28 & 29 & 30 & & & & \\
\hline \multirow{5}{*}{ Julho } & & & & & 1 & 2 & 3 & 4 \\
\hline & 4 & 5 & 6 & 7 & 8 & 9 & 10 & 11 \\
\hline & 5 & 12 & 13 & 14 & 15 & 16 & 17 & 18 \\
\hline & 6 & 19 & 20 & 21 & 22 & 23 & 24 & 25 \\
\hline & 7 & 26 & 27 & 28 & 29 & 30 & 31 & \\
\hline
\end{tabular}

\begin{tabular}{rrrrrrrrrr}
\hline \multirow{3}{*}{ Agosto } & 8 & 2 & 3 & 4 & 5 & 6 & 7 & 8 \\
& 9 & 9 & 10 & 11 & 12 & 13 & 14 & 15 \\
& 10 & 16 & 17 & 18 & 19 & 20 & 21 & 22 \\
& 11 & 23 & 24 & 25 & 26 & 27 & 28 & 29 \\
& 12 & 30 & 31 & & & & &
\end{tabular}

\begin{tabular}{|c|c|c|c|c|c|c|c|c|}
\hline & & & & 1 & 2 & 3 & 4 & 5 \\
\hline & 13 & 6 & 7 & 8 & 9 & 10 & 11 & 12 \\
\hline \multirow[t]{5}{*}{ Setembro } & 14 & 13 & 14 & 15 & 16 & 17 & 18 & 19 \\
\hline & 15 & 20 & 21 & 22 & 23 & 24 & 25 & 26 \\
\hline & 16 & 27 & 28 & 29 & 30 & & & \\
\hline & & & & & & 1 & 2 & 3 \\
\hline & 17 & 4 & 5 & 6 & 7 & 8 & 9 & 10 \\
\hline \multirow[t]{3}{*}{ outubro } & 18 & 11 & 12 & 13 & 14 & 15 & 16 & 17 \\
\hline & 19 & 18 & 19 & 20 & 21 & 22 & 23 & 24 \\
\hline & 20 & 25 & 26 & 27 & 28 & 29 & 30 & 31 \\
\hline
\end{tabular}


FIGURA 2 - Plano de amostragem - Relação dos dias correspondentes ao 20 período.

\begin{tabular}{|c|c|c|c|c|c|c|c|c|}
\hline Mēs & $\begin{array}{c}\text { Ordem } \\
\text { da } \\
\text { Semana }\end{array}$ & $\begin{array}{r}2 a \\
\text { feira }\end{array}$ & $\begin{array}{r}3 a . \\
\text { feira }\end{array}$ & $\begin{array}{r}4 a . \\
\text { feira }\end{array}$ & $\begin{array}{l}5 a . \\
\text { feira }\end{array}$ & $\begin{array}{c}6 a . \\
\text { feira }\end{array}$ & Sābado & Domingo \\
\hline \multirow{5}{*}{ Novembro } & 1 & 1 & 2 & 3 & 4 & 5 & 6 & 7 \\
\hline & 2 & 8 & 9 & 10 & 11 & 12 & 13 & 14 \\
\hline & 3 & 15 & 16 & 17 & 18 & 19 & 20 & 21 \\
\hline & 4 & 22 & 23 & 24 & 25 & 26 & 27 & 28 \\
\hline & 5 & 29 & 30 & & & & & \\
\hline \multirow{5}{*}{ Dezembro } & & & & 1 & 2 & 3 & 4 & 5 \\
\hline & 6 & 6 & 7 & 8 & 9 & 10 & 11 & 12 \\
\hline & 7 & 13 & 14 & 15 & 16 & 17 & 18 & 19 \\
\hline & 8 & 20 & 21 & 22 & 23 & 24 & 25 & 26 \\
\hline & 9 & 27 & 28 & 29 & 30 & 37 & & \\
\hline
\end{tabular}

\begin{tabular}{|c|c|c|c|c|c|c|c|c|}
\hline & & & & & & & 1 & 2 \\
\hline \multirow{5}{*}{ Janeiro } & 10 & 3 & 4 & 5 & 6 & 7 & 8 & 9 \\
\hline & 11 & 10 & 11 & 12 & 13 & 14 & 15 & 16 \\
\hline & 12 & 17 & 18 & 19 & 20 & 21 & 22 & 23 \\
\hline & 13 & 24. & 25 & 26 & 27 & 28 & 29 & 30 \\
\hline & 14 & 31 & & & & & & \\
\hline \multirow{5}{*}{ Fevereiro } & & & 1 & 2 & 3 & 4 & 5 & 6 \\
\hline & 15 & 7 & 8 & 9 & 10 & 11 & 12 & 13 \\
\hline & 16 & 14 & 15 & 16 & 17 & 18 & 19 & 20 \\
\hline & 17 & 21 & 22 & 23 & 24 & 25 & 26 & 27 \\
\hline & 18 & 28 & & & & & & \\
\hline \multirow{3}{*}{ Março } & & & 1 & 2 & 3 & 4 & 5 & 6 \\
\hline & 19 & 7 & 8 & 9 & 10 & 11 & 12 & 13 \\
\hline & 20 & 14 & 15 & 16 & 17 & 18 & 19 & 20 \\
\hline
\end{tabular}


Pretendeu-se que todas as usinas ficassem represen tadas nos 7 dias da semana, por isso, adotou-se alēm do cri tério "usina" o "dia da semana". Desta forma, os 560 conglo merados foram estratificados de acordo com esses dois critērios, em 28 estratos.

- Processo de amostragem

Utilizou-se amostragem sistemātica com intervalo de 2,5 obtendo-se aliquotas de tamanho 8, para cada dia da sema na (Figura nọ 3).

- Sorteio dos dias

Nos 140 dias de pesquisa tem-se 20 segundas-feiras, 20 terças-feiras, etc. Das 5 possiveis amostras que se pode obter, do estrato correspondente às segundas-feiras sortearam-se 4, aplicando-se o intervalo de 2,5; cada uma delas correspondeu por sorteio a uma das 4 usinas.

Desta forma, para cada usina selecionou-se uma amostra de 8 segundas-feiras sem que houvesse coincidéncia com as demais amostras e permitindo, tambēm, devido as condições de recurso do trabalho, que no máximo duas usinas fossem sor teadas para cada segunda-feira.

Procedeu-se analogamente em relação aos demais dias da semana.

Esta forma de sorteio permitiu que todos os dias da semana ficassem representados para as 4 usinas ( 8 para cada uma delas) bem espaçadas ao longo dos 140 dias, compreendendo 56 amostras para cada usina, totalizando 224 ao todo em cada período da pesquisa. 
FIgURA 3 - Plano para sorteio das possiveis amostras sistemá ticas de cada estrato

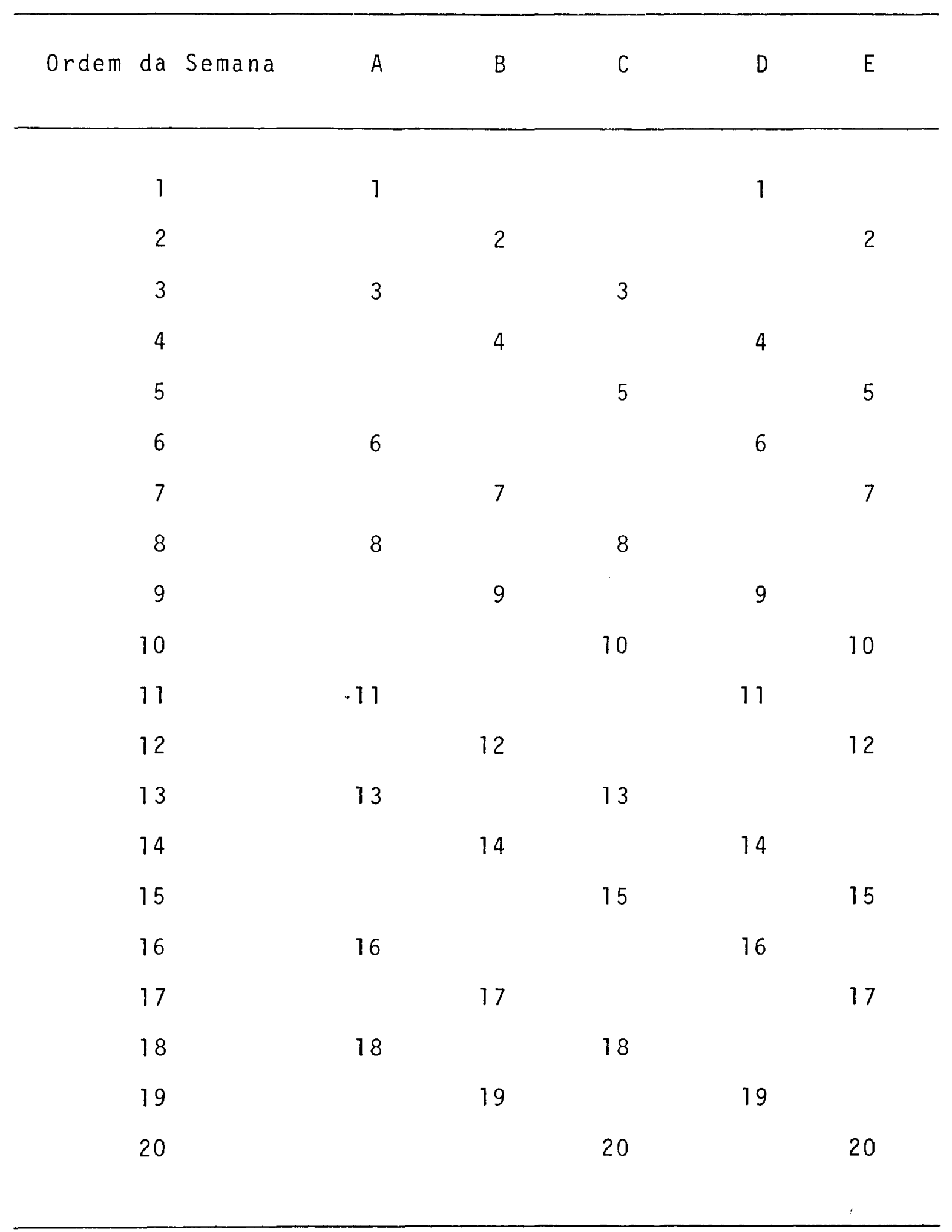


3.2 - Determinação de Aflatoxina

Na determinação de aflatoxina seguiu-se o mētodo desenvolvido por Della Rosa ${ }^{63}$. Somente na quantificação empregou-se a técnica proposta por Tuinstra 277 .

- Separação, extração e purificação

Em $100 \mathrm{ml}$ de leite colocados em erlenmeyer de 500 $\mathrm{ml}$ adicionaram-se $10 \mathrm{~g}$ de Kieselguhr e $300 \mathrm{ml}$ de acetona. Apōs a agitação de 3 minutos, filtrou-se atravēs de papel de filtro para um bequer de 1 litro (filtrado I).

o erlenmeyer e o papel de filtro foram lavados com $250 \mathrm{ml}$ de água, que foi recolhida para o mesmo bequer do fil trado I.

Ao filtrado I foram adicionados $25 \mathrm{ml}$ de solução de acetato de chumbo e agitou-se por 1 minuto. Após repouso de 5 minutos acrescentaram-se $12,5 \mathrm{ml}$ de solução saturada de sul fato de sódio, $12,5 \mathrm{~g}$ de Kieselguhr. Apōs agitação de 1 minu to, filtrou-se atravēs de papel de filtro adaptado em um funil de separação de 1 litro (filtrado II).

Ao filtrado I foram adicionados $180 \mathrm{ml}$ de hexano submetendo-se a uma agitação vigorosa de 1 minuto. Apōs repouso, a fase aquosa foi drenada para um bequer de 11 itro. e o hexano retirado do funil de separação pela parte superior, foi desprezado.

A fase aquosa foi recolocada no funil de separação, juntando-se a ela $90 \mathrm{ml}$ de solução de cloreto de sódio a $5 \%$. Em seguida procederam-se duas extrações com $180 \mathrm{ml}$ 
e $90 \mathrm{ml}$ de clorofórmio, sendo a fase aquosa desprezada e os extratos clorofórmicos transferidos para o funil de separa ção. Adicionaram-se então, $180 \mathrm{ml}$ de solução de cloreto de sódio a $5 \%$ e agitou-se vigorosamente por 1 minuto.

Apōs a separação das fases o clorofórmio foi drena do através de uma coluna de vidro com placa porosa e sem tor neira, contendo $45 \mathrm{~g}$ de sulfato de sōdio anidro para um ba1 ão de $500 \mathrm{ml}$. Lavou-se o bequer e a coluna de vidro com $40 \mathrm{ml}$ de clorofórmio.

o solvente, sob atmosfera de nitrogēnio, foi evaporado até à secura. Em seguida foi diluido novamente com clo rofórmio e transferido para um balão de $100 \mathrm{ml}$ e evaporado atē à secura, mantendo-se a atmosfera de nitrogēnio.

- Identificação e quantificação

o resíduo obtido na extração foi dissolvido com $100 \mu 1$ de clorofórmio." Agitou-se durante 1 minuto, e $20 \mu 1$ dessa solução foi aplicado em cromatoplaca (silica Gel G 60 , sem indicador de fluorescéncia) no ponto A (Figura nọ 4). Fo ram aplicados na mesma cromatoplaca nos pontos, B, C, D, E, F e G (Figura 4) volumes da solução do padrão de aflatoxina $M_{1}(0,1 \mu \mathrm{g} / \mathrm{ml})$ respectivamente, correspondentes às quantidades de $0,2 \mathrm{ng} ; 0,5 \mathrm{ng} ; 1 \mathrm{ng} ; 2 \mathrm{ng} ; 1 \mathrm{ng}$ e $1 \mathrm{ng}$.

A placa foi desenvolvida inicialmente em cuba equi librada, completamente vedada à luz, utilizando-se um sistema de solventes formado por éter dietîlico:metano1: ägua (94: 4,5:1,5). Após o desenvolvimento desse solvente, a placa foi colocada em estufa a $60^{\circ} \mathrm{C}$ para evaporação do mesmo. Subme teu-se a cromatografia a um segundo sistema de solventes for 
dimensões em $\mathrm{cm}$

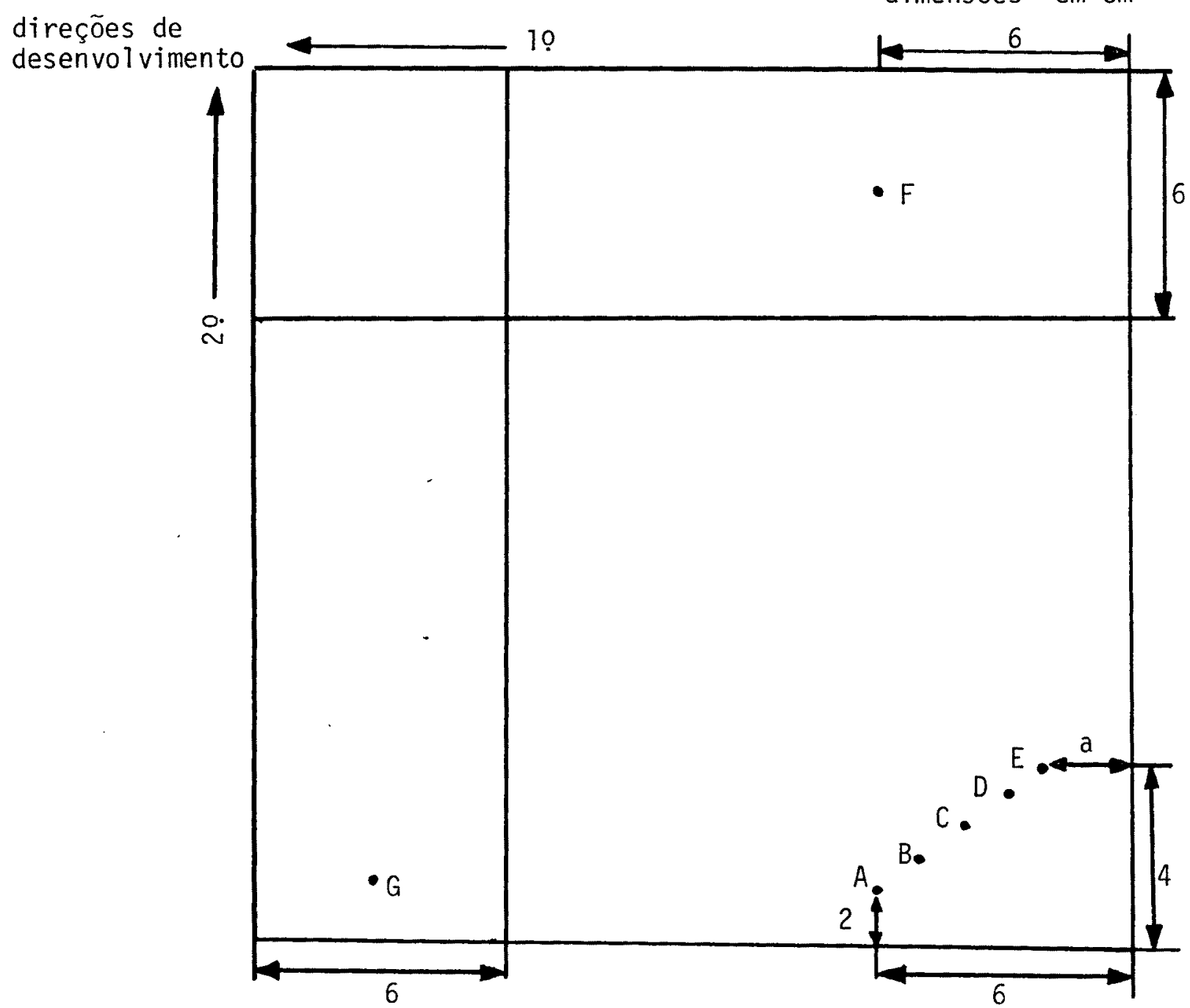

FIGURA 4 - Esquema do cromatograma bidimensional 
mado por clorofórmio:-acetona:metanol (90:10:2), em cuba vedada à luz, não equilibrada. Apōs desenvolvimento do solven te a placa foi colocada em estufa a $60^{\circ} \mathrm{C}$. Depois de evapora do o solvente, a aflatoxina foi identificada e quantificada por comparação visual com o padrão sob luz UV (gabinete de luz ultravioleta (hromatovue) de longo comprimento de onda $(366 \mathrm{~nm})$.

3.3 - Detecção de antibiōticos

Utilizou-se a dosagem microbiana para a detecção dos antibiōticos, empregando-se o método de difusão em placas e os microrganismos Sarcina Lutea ATCC $9341^{256}$.

- Preparação das placas

Em placas esterilizadas foram colocados $10 \mathrm{ml}$ do meio base, Penicillin Assay Base Agar esterilizado, quente. Apōs a solidificação desse meio, distribuiu-se em cada placa, $4 \mathrm{ml}$ do meio de cultura de superfície, Penicillin Assay Sedd Agar, devidamente inoculado com Sarcina lutea.

- Preparação da solução padrão

As diluições para a obtenção da solução padrão foram feitas em solução tampão ( $\mathrm{pH}$ 6). A ūitima das diluições, na qual se obteve uma concentração de penicilina de 0,05 unid/mi, 
foi feita com uma mistura da solução tampão $\mathrm{pH} 6$ e de leite isento de antibiōtico na proporção de $9: 1$.

- Exame da amostra

Todas as amostras de leite foram submetidas previamente a aquecimento de $80^{\circ} \mathrm{C}$ durante 5 minutos.

Usaram-se trés placas para cada teste, sendo exami nadas duas amostras por placa. Nas placas, utilizando-se um template colocou-se $0,2 \mathrm{ml}$ da solução padrão e $0,2 \mathrm{ml}$ de cada amostra a ser analisada. Incubou-se de 16 a 18 horas a $30( \pm 1)^{\circ} \mathrm{C}$. Depois da incubação mediu-se o diāmetro das zonas de inibição.

- Confirmação da presença de penicilina

Para identificar a atividade da penicilina, adicio nou-se penicilinase concentrada na razão de $0,5 \mathrm{ml}$ para $10 \mathrm{ml}$ da amostra. Misturou-se e incubou-se por 30 minutos a $37^{\circ} \mathrm{C}$. Usaram-se trés placas para cada amostra. Em cada uma das trēs placas, colocaram-se $0,2 \mathrm{ml}$ da solução padrão de 0,05 unid/m1, 0,2 ml da amostra não tratadas, e 0,2 ml da amostra tratada com penicilinase. Incubou-se por 16-18 horas por $30 \pm 1^{\circ} \mathrm{C}$.

Mediu-se o diāmetro de cada zona de inibição, calculou-se a média das lejturas do padrão, da amostra não tratada e da amostra tratada. 
- Interpretação

Uma zona de inibição na amostra não tratada e a ausēncia de inibição na amostra tratada com penicilinase é con siderado um teste positivo para penicilina. Se a média das lejturas das zonas de inibição das amostras tratadas com penicilinase tiver o mesmo diāmetro das leituras produzidas pe las amostras não tratadas, considera-se que não hā presença de penicilina. Se a média da zona de inibição produzida pela amostra tratada for menor em pelo menos, $0,1 \mathrm{~mm}$ que a mé dia da zona de inibição produzida pela amostra não tratada, considera-se que há a presença de penicilina e de outro inibidor não específico.

\section{4 - Identificação da āgua oxigenada}

0 mētodo seguido foi o da reação com solução de öxido de vanādio $110,290$.

Colocaram-se $10 \mathrm{ml}$ da amostra em um tubo de ensaio. Adicionaram-se 15 gotas da solução de ōxido de vanādio e agitou-se. Na presença de ägua oxigenada, aparece uma coloração rōsea ou vermelha.

3.5 - Identificação do formol

Utilizou-se nesta identificação a reação com solução de fluoroglucina 112 . 
Colocaram-se $15 \mathrm{ml}$ da amostra em um tubo de ensaio. Adicionaram-se $1 \mathrm{~m} 1$ da solução de fluroglucina a $1 \%$ e $2 \mathrm{ml}$ da solução de hidrōxido de sōdio a 10\% e agittou-se. Na presença de formol aparece uma coloração salmão.

3.6 - Identificação do Cloro (hipoclorito)

A identificação foi feita por meio da reação com solução de iodeto de potássio 190 .

Colocaram-se $5 \mathrm{ml}$ da amostra em um tubo de ensaio. Adicionaram-se $1,5 \mathrm{ml}$ da solução de iodeto de potāssio e agi tou-se. Na presença de cloro, aparece uma coloração amarela ou marrom clara. 
4 - RESULTADOS

A aflatoxina, embora em baixos níveis e em peque na proporção $(1,8 \%)$, fez-se presente nas quatro marcas, co mo indica a Tabela 4 .

Foi constatada alta prevaléncia de inibidores bacterianos, nos dois períodos de trabalho. No primeiro e no segundo períodos a proporção foi de $4,95 \%$ e $4,50 \%$ respectivamente, conforme as Tabelas 5 e 6 . Como pode-se verifi car, houve uma distribuição relativamente uniforme dos inibidores bacterianos nas quatro marcas examinadas; as marcas A, B e C com $5,40 \%$ e a marca D com 3,60\%, no primeiro perīodo; as marcas A e B, com $3,60 \%$ e as marcas C e D com 5,40\%, no segundo período. Nas tabelas seguintes podemos virificar separadamente a presença destes inibidores.

os resultados referentes à pesquisa de penicilina podem ser vistos nas Tabelas 7 e 8 . No primeiro período as marcas $A$ e $D$ apresentaram resíduos $(1,8 \%)$ e no segundo a mar ca $\mathrm{B}(1,8 \%)$.

Os inibidores não identificados estão expressos nas Tabelas 9 e 10. Como pode-se constatar foi alta a incidén cia destes no decorrer do estudo. As marcas A e C apresentaram resultados positivos em $3,6 \%$ das amostras, a marca $B$ em $5,40 \%$ e a marca $D$ em 1,80\%, no primeiro periodo; as mar- 
cas $A, B$ e $C$ em $3,60 \%$ e a marca $B$ em $1,80 \%$, no segundo perío do.

A presença de ägua oxigenada, formol e cloro pode ser observada nas Tabelas 11 e 12. Houve uma baixa proporção de àgua oxigenada e formol e ausēncia de cloro. A par tir dessa constatação, pode-se concluir que os inibidores não identificados presentes no leite, provavelmente serão outros antibiōticos que não a penicilina. A possibilidade de serem inibidores bacterianos naturais do leite é descartada de vido aos cuidados tomados na parte experimental (aquecimento a $\left.80^{\circ} \mathrm{C}\right)$. Existe, obviamente, a possibilidade da presen ça de outras substāncias desconhecidas, que poderão atuar tambēm como inibidores bacterianos. Entretanto, o fato de que hā um uso abusivo e amplamente disseminado de antibiótị cos por parte dos pecuaristas no nosso meio, torna mais plau sível a hipōtese de serem resíduos de antibiōticos. 
TABELA 4 - Incidéncia de aflatoxina nas amostras de leite correspondente as quatro marcas de maior consumo analisadas no 10 período (14.06.82 - 31.10.82).

\begin{tabular}{ccccc}
\hline Marca & $\begin{array}{c}\text { Total de amostras } \\
\text { analisadas }\end{array}$ & $\begin{array}{c}\text { nọ de amostras } \\
\text { positivas }\end{array}$ & $\mu \mathrm{g} / 1$ & $\%$ \\
\hline A & 56 & 1 & 0,025 & 1,80 \\
B & 56 & 1 & 0,025 & 1,80 \\
C & 56 & 1 & Traços & 1,80 \\
D & 56 & 1 & & 1,80 \\
\hline Total & 224 & 4 & & 1,80 \\
\hline
\end{tabular}

TABELA 5 - Incidência de inibidores bacterianos nas amostras de leite correspondente as quatro marcas de maior consumo analisada no 19 período $(14.06 .82$ $-31.10 .82)$

\begin{tabular}{cccc} 
Marca & $\begin{array}{c}\text { Total de amostras } \\
\text { analisadas }\end{array}$ & $\begin{array}{c}\text { no de amostras } \\
\text { positivas }\end{array}$ & $\%$ \\
\hline A & 56 & 3 & 5,40 \\
B & 56 & 3 & 5,40 \\
C & 56 & 3 & 5,40 \\
D & 56 & 2 & 3,60 \\
\hline Total & 224 & 11 & 4,95 \\
\hline
\end{tabular}


TABELA 6 - Incidência de inibidores bacterianos nas amostras de leite correspondente as quatro marcas de maior consumo analisadas no 20 período $(01.11 .82$ $-20.03 .83)$.

\begin{tabular}{cccc}
\hline Marca & $\begin{array}{c}\text { Total de amostras } \\
\text { analisadas }\end{array}$ & $\begin{array}{c}\text { no de amostras } \\
\text { positivas }\end{array}$ & $\%$ \\
\hline A & 56 & 2 & 3,60 \\
B & 56 & 2 & 3,60 \\
C & 56 & 3 & 5,40 \\
D & 56 & 3 & $5,40^{\circ}$ \\
\hline Total & 224 & 10 & 4,50 \\
\hline
\end{tabular}

TABELA 7 - Incidéncia de penicilina nas amostras de leite correspondente as quatro marcas de maior consumo analisadas no 1 o período $(14.06 .82-31.10 .82)$.

\begin{tabular}{cccc} 
Marca & $\begin{array}{c}\text { Total de amostras } \\
\text { analisadas }\end{array}$ & $\begin{array}{c}\text { no de amostras } \\
\text { positivas }\end{array}$ & $\%$ \\
A & 56 & 1 & 1,8 \\
B & 56 & - & - \\
C & 56 & 1 & 1,8 \\
D & 56 & 2 & 0,9 \\
\hline Total & 224 & & \\
\hline
\end{tabular}


TABELA 8 - Incidéncia de penicilina nas amostras de leite correspondente as quatro marcas de maior consumo analisadas no 20 período (01.11.82 - 20.03.83).

\begin{tabular}{cccc} 
Marca & $\begin{array}{c}\text { Total de amostras } \\
\text { analisadas }\end{array}$ & $\begin{array}{c}\text { no de amostras } \\
\text { positivas }\end{array}$ & \% \\
A & 56 & 1 & 1,80 \\
B & 56 & - & - \\
C & 56 & - & 0,45 \\
D & 56 & 1 & \\
\hline Total & 224 & - & - \\
\hline
\end{tabular}

TABELA 9 - Incidēncia de inibidores não identificados nas amostras de leite correspondente as quatro marcas de maior consumo analisadas no 10 período $(14.06 .82-31.10 .82)$

\begin{tabular}{cccc} 
Marca & $\begin{array}{c}\text { Total de amostras } \\
\text { analisadas }\end{array}$ & $\begin{array}{c}\text { no de amostras } \\
\text { positivas }\end{array}$ & $\%$ \\
A & 56 & 2 & 3,60 \\
B & 56 & 3 & 5,40 \\
C & 56 & 2 & 3,60 \\
D & 56 & 1 & 1,80 \\
\hline
\end{tabular}


TABELA 10 - Incidēncia de inibidores não identificados nas amostras de leite correspondente as quatro marcas de maior consumo analisadas no 20 período $(01.11 .82-20.03 .83)$.

\begin{tabular}{cccc} 
Marca & $\begin{array}{c}\text { Total de amostras } \\
\text { analisadas }\end{array}$ & $\begin{array}{c}\text { no de amostras } \\
\text { positivas }\end{array}$ & $\%$ \\
A & 56 & 2 & 3,60 \\
B & 56 & 1 & 1,80 \\
C & 56 & 2 & 3,60 \\
D & 56 & 2 & 3,60 \\
\hline Total & & 7 & 3,15 \\
\hline
\end{tabular}


TABELA 11 - Incidencia de água oxigenada, formol e hipoclorito nas amostras de leite correspondente as quatro marcas de maior consumo analisadas no 19 período (14.06.82 - 31.10.82).

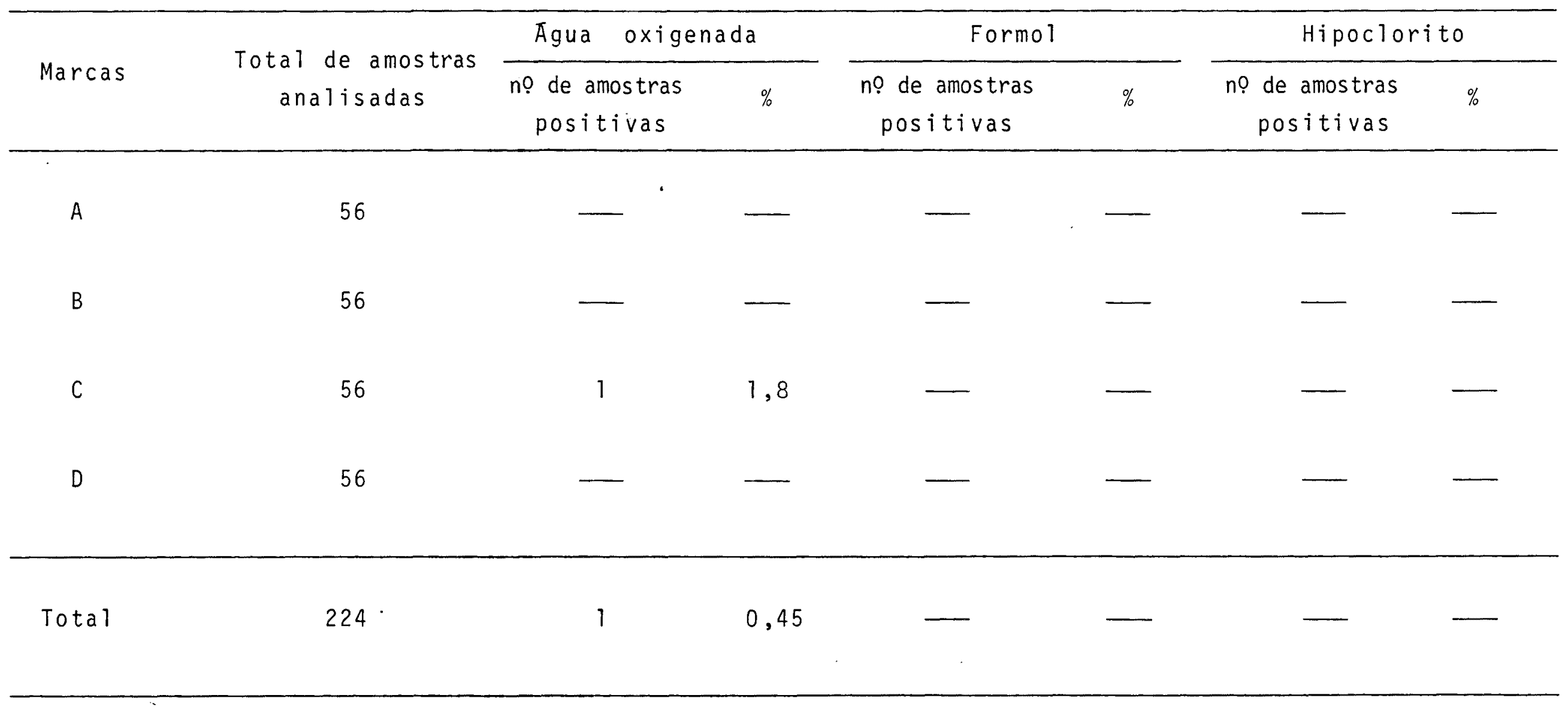


TABELA 12 - Incidēncia de āgua oxigenada, formol e hipoclorito nas amostras de leite correspondente as quatro marcas de maior consumo analisadas no 20 período (01.11.82 - 20.03.83).

\begin{tabular}{|c|c|c|c|c|c|c|c|c|}
\hline \multirow[b]{2}{*}{ Marcas } & \multirow{2}{*}{$\begin{array}{c}\text { Total de amostras } \\
\text { analisadas }\end{array}$} & Āgua & \multicolumn{2}{|c|}{ oxigenada } & \multicolumn{2}{|c|}{ Formol } & \multicolumn{2}{|c|}{ Hiploclorito } \\
\hline & & $\begin{array}{l}\text { nọ de amo } \\
\text { positil }\end{array}$ & $\begin{array}{l}\text { tras } \\
\text { las }\end{array}$ & $\%$ & $\begin{array}{c}\text { no de amostras } \\
\text { positivas }\end{array}$ & $\%$ & $\begin{array}{c}\text { nọ de amostras } \\
\text { positivas }\end{array}$ & $\%$ \\
\hline A & 56 & - & & - & - & - & - & $\longrightarrow$ \\
\hline$B$ & 56 & $\longrightarrow$ & & - & - & - & - & $\underline{-}$ \\
\hline C & 56 & - & & - & 1 & 1,8 & - & 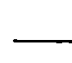 \\
\hline D & 56 & 1 & & 1,8 & - & - & - & 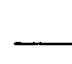 \\
\hline Total & 224 & 1 & & 0,45 & 1 & 0,45 & - & 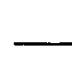 \\
\hline
\end{tabular}


$5-$ DISCUSSAO

Como jā foi referido, as anālises de aflatoxina $M_{1}$ no leite, foram efetuadas no período de 14 de junho a 31 de outubro de 1982, meses onde predominam temperaturas mais bai xas. Também, por ser período de entressafra, geralmente o consumo de ração pelas vacas é bem mais elevado e, como há uma relação direta entre a ingestão de aflatoxina $B_{1}$ e a incidencia de aflatoxina $M_{1}$ no leite, seria maior a probabili dade de ser encontrada.

A pequena proporção e os baixos níveis estão apresentados na Tabela 4. Nas quatro amostras as concentrações foram inferiores aos limites fixados pelo FDA ou seja $0,5 \mu \mathrm{g} /$ $/ k g$. Entretanto, convém ressaltar que, especificamente, no ano em questão o inverno foi ameno não prejudicando as pasta gens, ocorrendo consequentemente menor consumo de ração. Por outro lado, o fato de se ter encontrado amostras positivas constituiu-se uma alerta à saūde pública, quanto a necessida de de se estabelecer uma legislação específica sobre a presença deste contaminante no leite, paralelamente com uma ação educativa ao produtor.

os estudos de Pozzobon 202 e Sabino 219 tambëm mostraram pequena incidencia de aflatoxina nas amostras de leite analisadas.

Entretanto, os resultados obtidos diferem dos encontrâdos em diversos países, onde a incidência e os nĩveis 
de aflatoxina foram sempre mais elevados $23,24,50,86,207,211$, 271,285. Esta diferença foi atribuida a alimentação e as condições de armazenamento.

A qualidade e a procedéncia da ração é um fator im portante na contaminação dos produtos leiteiros. Segundo a Organização Mundial da Saūde (OMS), para combater as micotoxinas hà necessidade de se prevenir e de se reduzir a nîveis inōcuos a contaminação dos alimentos e das rações. Para tan to, o fundamental é estabelecer métodos adequados de colheita, tratamento, armazenamento, transporte e distribuição, a fim de impedir a formação desses contaminantes. Torna-se ne cessārio manter uma vigiláncia continua dos produtos de elevado risco, destinados à alimentação humana e animal.

No Brasil,as condições de fabricação e armazenamen to de rações parecem não favorecer a formação e proliferação de micotoxinas. Além disso as condições climáticas por não serem muito rigorosas, torna desnecessārio o armazenamento de grandes quantidades de rações.

Nos paises onde foram realizadas pesquisas sobre a presença de aflatoxina no leite e derivados, as condiçōes de armazenamento e fabricação são totalmente diversas às do Bra si1. Nesses países, muitas vezes os ingredientes destinados à produção de rações são importados aumentando o risco de contaminação, em virtude das condições de armazenamento e de transporte.

A baixa incidência e a baixa concentração de aftatoxina $M_{1}$ poderia ter ocorrido pelo fato de que o leite tipo "B" tenha sido homogeneizado, misturando-se com o de vārias procedencias. Desta maneira, a mistura de produto com e sem aflatoxina levaria à diluição destas e à consequente dificul dade de deteç̧ão. 
Entretanto, a constatação de aflatoxina no leite, embora em baixos teores, indica que está havendo ingestão de ração com Aspergilus. A magnitude pode ter sido pequena no momento da pesquisa, o que não dā segurança sobre o que possa ocorrer futuramente. Alëm disso, Sabino 218 constatou que alimentos e rações do Estado de São Paulo e de outras regiões do Brasil no período de 1971 a 1979, estavam contaminadas com aflatoxinas $B_{1}$, em limites que variaram de 50 a $7.800 \mu \mathrm{g} / \mathrm{kg}$, superiores aos valores tolerados pela legislação brasileira $(30 \mu \mathrm{g} / \mathrm{kg})$. Por isso, não serā exagero enfatizar a necessidade de uma vigilância constante pelas autoridades sanitárias, quanto à presença de aflatoxinas $B_{1}$ em alimentos e rações animais comercializadas.

Quanto aos inibidores bacterianos, a literatura tem mostrado que a presença destes no leite tem sido um problema mundial, embora ocorra variações nas proporções de contamina ção de país para país60,113,131,132,193,200. Nas pesquisas realizadas no Brasil também foram constatados diferentes valores de incidéncia, todos superiores aos deste trabalho, co mo mostram os estudos de Mello Filho $177,178,179$, Reis 212 , Mel Ter ${ }^{175}$, Tavares de Macedo ${ }^{161}$, Fagundes ${ }^{76}$ e Barros \& Perches $^{22}$.

Os problemas jā referidos decorrentes da estabulação e da ordenha mecânica, aliados à preocupação do produtor em ter maiores cuidados com o gado, em virtude do investi mento realizado, acentua o uso indiscriminado de antibiōti cos, sem se ter o cuidado de desprezar o leite das vacas doentes nas 72 horas subsequentes ao tratamento, contrariando assim a legislação em vigor.

Pelo que podemos ver, no primeiro período houve maior incidência de penicilina (Tabela 7) do que no segundo (Ta 
bela 8). Esta pequena diferença pode ser atribuída ao acaso não havendo diferenças no tratamento e condições de criação de gado entre os meses frios e quentes. Nos paises europeus a incidencia é maior no inverno do que no verão, aumentando a tendência de contaminação durante o perĩodo de parição, quan do o gado é mantido mais estabulado. Nestes países e mesmo nos U.S.A., a penicilina ainda é um dos antibiōticos mais utilizados.

$\mathrm{Na}$ identificação de antibiōticos, concentramos nos sa atenção nos resíduos de penicilina, em virtude dos aciden tes alérgicos observados nos consumidores de leite e dos problemas que acarretam à indústria de laticínios. 0 resíduo "peniciloila", surge no leite logo apōs a administração de penicilina por via intramamāria. Inicialmente o teor ē muito inferior ao dos resíduos de penicilina livre; trés a quatro dias apōs o tratamento, não hā mais detecção de traços de "peniciloila". O tempo de transporte, de comercialização e os processos industriais não provocam diminuição destes re sĩduos. Anālises feitas apōs tratamento térmico no lugar de constatar diminuição do teor de resíduo de "peniciloila" como poderia se esperar, demonstraram o contrārio; o efeito do calor ocasiona aumento do teor. Esse aumento ocorre pelo fa to de que uma parte da penicitina livre é. transformada sob a ação do calor em grupamentos "peniciloila" que se conjugam as proteínas do leite.

A prevaléncia de inibidores não identificados (Tabelas 9 e 10) foi bastante significativa nos dois periodos, com $3,57 \%$ e $3,27 \%$ de positividade. Embora estes inibidores não tenham sido identificados, seguramente não correspondiam à presença de formol, de àgua oxigenada e de cloro cujas iden tificações foram feitas. Este fato sugere que sejam resi- 
duos de antibióticos, pelo uso indiscriminado entre os produ tores sem nenhum critério e fiscalização. O cloranfenicol, por exemplo é normalmente utilizado no Brasil sem nenhuma res trição, embora o Food and Drug Administration (F.D.A.), e a Organização Mundial da Saūde (O.M.S.) jā o tenham proibido nos produtos de origem animal e não deve ser empregado para nenhum fim que possa dar lugar à presença de alimentos.

A Organização das Nações Unidas para a Alimentação e a Agricultura (F.A.0.) e a Organização Mundial da Saūde (O.M.S.) $)^{59}$ estabeleceram normas para a utilização de antibiō ticos em alimentos somente como aditivos intencionais. Permitem seu emprego como aditivos diretos de alimentos cujo uso terapēutico não seja de grande importāncia e que não ocasionem resistência cruzada ou não prejudiquem de nenhuma outra forma o emprego terapêutico de outros antibiōticos em medic $\underline{i}$ na humana ou veterināria.

os resultados encontrados no presente estudo quanto à incidência de antibióticos no leite evidenciam que no ano em questão, milhares de pessoas do nosso estado o consumiram involuntariamente, com todos os danos que seu consumo pode ocasionar. Desnecessārio se torna enfatizar a necessidade urgente de uma ampla ação educativa junto ao produtor e à população, seguida de uma fiscalização rigorosa das vārias etapas da trajetōria do produto desde o animal até o con sumidor.

A incidēncia de àgua oxigenada foi pequena (Tabelas $11 \mathrm{e}$ 12).

Sua presença no leite tem sido defendida por vārios autores. Este assunto é constantemente abordado pela F.A.O e pela O.M.S., que estabeleceram critérios para o seu uso, quando por motivos técnicos ou económicos não permitem 
utilizar instalações de refrigeração para manter a qualidade do leite cru. Entretanto, essas organizações chamam a atenção para o fato de que o emprego desse processo em laticínios pode se tornar sistemätico e incentivar os produtores a abandonarem todas as condições higiênicas de obtenção e de transporte do leite.

Muitas vezes, além dos conservantes antissēpticos são identificados no leite outras substâncias, geralmente de correntes da higienização do vasilhame e do equipamento empregados na indústria de laticínios, capazes de agir como inibidores do crescimento bacteriano, mesmo em concentrações de 10 a 30 p.p.m. E o caso do formol e do cloro que apesar de apresentarem ação bactericida, não são indicados para uso em alimentos, porque produzem alterações na digestibilidade, gos to e aroma. Nas amostras analisadas houve baixa positividade para o formol e auséncia de cloro (Tabelas 10 e 11). Apesar da Legislação Brasileira ter abordado tardiamente o problema dos conservantes e inibidores, atualmen te o leite beneficiado que apresentar esses contaminantes se rā considerado inadequado para a alimentação humana, podendo ser utilizado na fabricação industrial de sabão ou caseína; a legislação estabelece tambēm que antes do empacotamento do produto, deverão ser efetuadas pesquisas de conservantes, ini bidores, reconstituintes da densidade e neutralizantes. Entretanto, os antibióticos que parecem ser inibidores bacterianos mais encontrados não são analisados de forma especĩfi ca. Apenas é feito esporadicamente um teste qualitativo (C.T.T.) que detecta a presença de qualquer inibidor, seja ele antibiō tico ou não.

Podemos considerar os alimentos como um dos principais veículos de transferéncia de substäncias nocivas do 
meio ambiente para o homem. Ele pode transportar resĩduos de pesticidas, antibióticos, traços de fertilizantes e outros contaminantes.

Atualmente esse problema tem-se agravado, cada vez mais, em virtude do crescimento da população, que exige um aumento contínuo na produção de alimentos, provocando, conse quentemente sérios problemas relacionados à conservação dos mesmos. A cadeia que se estende do produtor ao consumidor é longa, o que torna necessārio a utilização de preservativos e aditivos que prolonguem a vida comercial e melhorem o sabor, a cor e a consisténcia dos produtos. Entretanto, em qualquer etapa dessa trajetōria existe riscos de prejuízo na qualidade do alimento. Por exemplo, hà a possibilidade de contaminação dos ingredientes e dos equipamentos, de contaminação cru zada durante a fabricação, de refrigeração deficiente e de falta de higiene. A ação da Saūde Pūblica deve ser planejada levando-se em consideração a totalidade desses fatores. Uma legislação por mais rigorosa que seja não terá condições de resolver o problema se não houver um sistema de inspeção eficiente apoiado por uma rede de laboratórios especializados. No caso específico do leite, atualmente hā uma inspeção deficiente junto às indústrias de laticínios, precária nas plataformas de recepção e ausente nas propriedades rurais. * Quanto a presença de aflatoxina $M_{1}$ no leite, o F.D.A. tem procurado resolver o problema mais pelo controle da afla toxina $B_{1}$ em rações. Para tanto, estabeleceu um limite de $20 \mathrm{ng} / \mathrm{g}(\mathrm{ppb})$ para o total das aflatoxinas $\left(B_{1}+B_{2}+G_{1}+G_{2}\right)$ em todos os alimentos ou ingredientes para alimentos animal e humano que, se observado, serā evitada a presença de aflatoxina $M_{1}$ no leite.

0 F.D.A. tambēm mantēm um sistema de inspeção rigo 
roso em relação a presença de antibióticos no leite. Embora, este sistema seja eficiente e tenha apoio de uma ampla rede de laboratōrios especializados, o seu controle se torna bastante difícil pelos motivos jā expostos. Entretanto, neste setor o governo recebe grande colaboração de empresas particu lares. Segundo Schoech 227 as grandes cooperativas do U.S.A., executam um sistema prōprio de inspeção sobre os fornecedores do produto. Estas cooperativas possuem uma rede de laboratōrios, onde são feitos testes de gordura e de antibióticos. Parte do leite recebido é separado para anālise. Cada amostra analisada é constituída por uma mistura do leite proveniente de vārios produtores. Como o leite recebido somente serā beneficiado no dia seguinte hā tempo suficiente tambēm para pesquisa rāpida de antibiōticos. Caso haja algum resultado positivo, o leite fornecido por cada produtor correspondente aquela amostra, será testado individualmente, com a finalidade de identificar o infrator.

Atualmente, no Brasil, uma inspeção eficaz sobre qualidade do leite é muitó difícil. No caso da aflatoxina, pode rá ser adotado o exemplo do F.D.A.. Entretanto, para os anti bióticos, jā serā mais complexo por falta de uma estrutura administrativa. Talvez uma maneira de resolver mais rapidamen te este problema seja a adoção de testes rāpidos para detecção de contaminantes, principalmente de inibidores bacteria nos, e que possam ser realizados na plataforma de recepção.

outro elemento de fundamental importāncia será educação dos produtores, dos fabricantes e do consumidor. 0 exem plo apontado pelo F.D.A. 113 mostrou que a incidéncia de anti biōtico no leite, no U.S.A., diminuiu em decorrēncia de uma atuação educativa junto ao produtor. 


\section{6 - CONCLUSOES}

De acordo com as condições e os resultados do presente trabalho, podemos concluir:

- A incidência de aflatoxina $M_{1}$ no leite tipo "B" comercializado na cidade de. São Paulo representado pelas qua - tro marcas de maior consumo foi pequena e os niveis encontrados foram baixos. Entretanto, ficou colocado o problema da necessidade do estabelecimento de limites de toleräncia deste contaminante no leite, ausentes na nossa legislação.

- A alta porcentagem de inibidores bacterianos encontrados nas amostras analisadas torna enfätica a necessidade da atuação da Saūde Pública quer seja através da ins peção, quer seja através de amplos programas educativos junto a população envolvida na cadeia de produção.

- As contaminações detectadas mantiveram-se sempre dentro de um mesmo nível, nas quatro marcas estudadas, o que torna o problema mais grave na medida em que se detecta a má qualidade do leite comercializado em São Paulo. 
- As marcas de leite objeto desta pesquisa, revelaram con taminação por inibidores bacterianos, contrariando a legislação em vigor.

- Há a necessidade de se pesquisar e adotar testes rápidos para detecção de contaminantes no lejte que possam ser realizados na plataforma de recepção.

- Há a necessidade do estabelecimento de uma legislação que trate especificamente da presença de antibióticos no leite. 
7 - REFERENCIAS BIBLIOGRAFICAS

1 - AFZAL, M. et al. - Incidence of aflatoxins and aflatoxin producing fungi in animal feedstuffs. Mycopathologia, 69: $149-51,1979$.

2 - Albright, J.L. et al. - Antibiotics in milk: a Review. J. Dairy Sci., 44:779-807, 1961 .

3 - AllCROFT, R. \& CARNAGHAN, R.B.A. - Groundnut toxicity. A. flavus toxin (aflatoxin) in animal products: preliminary communication. Vet. Rec., 74:863-86, 1962 .

4 - AllCROFT, R. \& CARNAGHAN, R.B.A. - Groundnut toxicity: an examination for toxin in human food products from animal fed toxic groundnut mea1. Vet. Rec., 75:259$63,1963$.

5 - ALLCROFT, R. \& LEWIS, G. - Groundnut toxicity in cattle: experimental poisoning of calves and a report on clinical effects in older cattle. Vet. Rec., 75:487$93,1963$. 
6 - AllCROFT, R. \& ROBERTS, B.A. - Toxic groundnut meal: the relationship between aflatoxin $B_{1}$ intake by cows and excretion of aflatoxin M, in milk. Vet. Rec., 82: $116-8,1968$.

7 - AlLCROFT, R. et a1. - A toxic factor in Brazilian groundnut mea 1. Vet.Rec., 73:428-9, 1961.

8 - ALLCROFT, R. et al. - Metabolism of aflatoxin in sheep: excretion of the "milk toxin". Nature, London, 209: $154-5,1966$.

9 - ALPERT, M.E. et al. - Primary hepatoma in Uganda, a prospective clinical and epidemiologic study in forty - six patients. Amer. J.Med., 46:794-802, 1969.

10 - ALPERT, M.E. et al. - Association between aflatoxin content of food hepatoma frequency in Uganda. Câncer, 28: $253-60,1971$.

11 - ANGSUBHAKORN, S. et al. - Aflatoxins in horses. J. Amer. vet. med. Ass., 178:274-8, 1981.

12 - ANIFANTAKIS, E.M. - Excretion rates of antibiotics in milk of sheep an their effect on yorgut production. J. Dairy Sci., 65:426-9, 1982 .

13 - APPLEBAUM, R.S. \& MARTH, E.H. - Fate of aflatoxin $M_{1}$ in cottage cheese. J.Food Protec., 45:903-4, 1982.

14 - APPlebaum, R.S. et a1. - Aflatoxin: toxicity to dajry cattle and ocurrence in milk and milk products - A review. J. Food Protec., 45:752-7, 1982. 
15 - APPLEBAUM, R.S. et a 1. - Responses of dairy cows to dietary aflatoxin: feed intake and yield, toxin content and quality of milk of cows treated with pure and impure aflatoxin. J. Dairy Sci., 65:15038,1982 .

16 - ARMBRECHT, B.H. - Aflatoxin residues in food and feed derived from plant and animal sources. In: Gunther, F.A. \& Gunther, J.D. Residue Rev., vol. 41 , Spring-Verlag, New York, 1972, p. 13-54.

17 - ARSECUleratne, S.N. \& SilVA, L.M. - Aflatoxin contamination of coconut products. Ceylon J.med. Sci., 20:6075,1971 .

18 - ASPLIN, F.D. \& CARNAGHAN, R.B.A. - The toxicity of certain groundnut meals for poultry with special reference to their effect on ducklings and chickens. Vet. Rec., 73:.1215-9, 1961 .

19 - AYNSLEY, L.H. \& HUGHES, D.L. - Neomycin as a treatment for bovine mastites. Brit. vet. J., 110:403-10, 1954.

20 - BAINTON, J. \& JONES, B.D. - Mycotoxins on foods and feeds their occurrence and significance. Ann. Nutr., $31: 415-24,1977$.

21 - BALZER, I. et al. - Natural contamination of corn with mycotoxins in Yogoslavia. Ann. Nutr., 31:425-30, 1977 . 
22 - BARROS, V.R.M. \& PERCHES, E.M.C. - Pesquisa de inibidores no leite tipo "B", distribuido ao consumo da gran de São Paulo. Rev. Inst. Laticinios Candito Tostes, 36 $: 39-42,1981$.

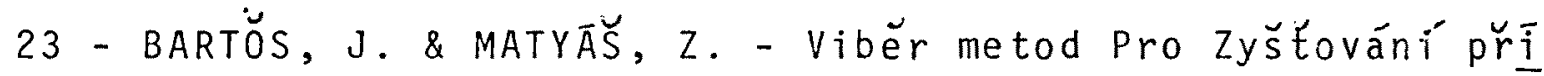
tomnosti aflatoxinú v tekutēm Mléce. Vet. Med., Praha, 23:559-67, 1978 .

24 - BARTÖS, J. \& MATÝY̆S, Z. - Pruzkum Přrítomnosti Aflatoxinu $M_{1} V M T e ̄ c e ~ Z$ Prvovýroby. Vet. Med., Praha, 26:41923,1981 .

25 - BAUR, F.J. \& ARMSTRONG, J.C. - Collaborative study of a modified method for the determination of aflatoxins in coprameal and coconut. J.Ass. Offic. Anal. Chem., 54:874-8, 1971 .

26 - BEAN, G.A. et al. - Occurence of aflatoxins and aflatoxin-producing strains of Asperfillus spp. in soybeans. Appl. Microbio1., 24:437-9, 1972.

27 - BERNARD, H. - Le plan G.T.V. de leitte contre les mammi tes. Resultats pratiques dans le Departement de la Loire. Lion, 1979. (Tese de Doutoramento). Apud: RUIZ, R.L. - 0 Problema das mastites nos bovinos. Prevenção e tratamento. Hig. Alim., 2:55-63, 1983.

28 - BERRIDGE, N.I. - Penicillin in milk III. The effect on low concentration of penicillin on the rate of acid production by starter cultures. J. Dairy Res., 23: $348-54,1956$. 
29 - BLOBEL, H. - Concentration of penicillin in milk secretions and blood serums of cows following intramamary infusion of one or more quarters. Amer. vet. med. Ass., 137:110, 1960.

30 - BOOTH, J. - Antibiotic residues in milk. Practice, London, 4 : 100-9, 1982.

31 - BOUTibonnes, P. \& JACQuet, J. - Sur la frēquence de l'aflatoxine e de Aspergillus dans les aliments. C. R. Soc. Bio1., 163:1119-24, 1969 .

32 - Boutrif, E. et al. - Aflatoxin in Tunisian foods and foodstuffs. Ann. Nutr., 31:431-4, 1977.

33 - BRAMLEY, A.J. - Source of Streptococcus uberis in the dairy herd. I. Isolation from bovine faece and from straw bedding of cattle. J. Dairy Res., 49:369-73, 1982 .

34 - BREWINGTON, C.R. et al. - Survey of commercial milk samples for aflatoxin $M_{1}$. J. Dairy Sci., 53:150910,1970 .

35 - BRIGHTLING, P. - Antibacterial activity of cows milk following therapy with oxytetracycline uterine pessaries. Aust. vet. J., 57:143-4, 1987.

36 - BRYDEN, W.L. et al. - Survey of Australian feedstuffs for toxigenic strains of Aspergillus flavus and for aflatoxin factor. Aust. vet. J., 51:491-3, 1975. 
37 - BRYDEN, W.L. et al. - Aflatoxin contamination of Australian animal feeds ans suspected cases of mycotoxicoses. Aust. vet. J., 56:176-80, 1980.

38 - BURDASPAL, P.A. - Aflatoxinas em alimentos. Alimentaria, $14: 21-7,1978$.

39 - BUTLER, W.H. - Acute toxicity of aflatoxin $B_{1}$ in rats. Brit. J. Cancer, 18:756-62, 1964.

40 - ButLeR, W.H. - Review of the toxicology of aflatoxin. Pure App1. Chem., 35:217-22, 1973.

41 - BUTLER, W.H. \& CLIFFORD, J.I. - Extration of aflatoxin from rats 1iver. Nature, London, 206:1045-6, 1965.

42 - CAMPBELL, T.C. \& STOLOFF, L. - Implication of Mycotoxins for human health. J.Agr. Food Chem., 22:1006-15, 1974.

43 - CAMpbel, T.C. \& hayes, J.R. - The role of aflatoxin metabolism in its toxic 1esion. Toxicol. Appl. Pharmaco1., 35:199-221, 1976 .

44 - CANTON, J.H. et al. - The carcinogenicity of aflatoxin $M_{1}$ in rainbow trout. Food Cosmet. Toxicol., 13: $441-3,1975$.

45 - CARNAGHAN, R.B.A. \& SARgEANT, K. - The toxicity of certain ground-nut meals to poultry. Vet. Rec., 73:726-7, 1961 . 
46 - CeCIliA, C.A. - Enciclopedia de la inspecciōn veterināria y anālisis de alimentos. Madrid, Espasa-Calpe, 1980, p. 1157 .

47 - CECILIA, C.A. - Enfermedades infecciosas y colectivas de las reses de ordeño. Enciclopedia de la leche. Madrid, Espasa-Calpe, 1956, p. 126-48.

48 - CHURCHILL, E.S. et al. - A report on the modified phosphatase method of detecting antibiotic substances in milk. Milk Plant Monthly, 40:28-31, 1951.

49 - CLARKSON, J.R. - Aflatoxicosis in swine: a review. Vet. Hum. Toxicol., 22:20-2, 1980 .

50 - COBB, W.Y. - Aflatoxin in the Southeastern. United States: was 1977 exceptional? Assoc. Food Drug Off-Q. Bul1., 43: $99-107,1979$.

51 - COELHO, W.P. Mastite bovina. In: MANUAL veterinārio. 4.ed. Guarulhos, Pfeizer, 1979, p. 107-21.

52 - COGAN, T.M. - Susceptibility of cheese and yoghurt starter bacteria to antibiotics. App1. Microbiol., $23: 960-5,1972$.

53 - COLLET, J.C. \& REgNiER, J.M. - Contamination par mycotoxines de mais conservēs en cribs et visiblement alterés. Ann. Nutr., 31:447-57, 1977. 
54 - COLLINS, E.B. \& DIRAR, H.A. - Effects of hydrogen peroxide on growth of Pseudomonas fragi and Shelf life of pasteurized half-and-half. J. Dairy Sci., 52:962-7, 1969.

55 - COLlins, E.B. - Preservatives in dairy products. J. Dairy Sci., 54:1482-92, 1971 .

56 - COMISSÁO NACIONAL DE NORMAS E PADROES PARA ALIMENTOS Resolução 34, de outubro de 1976. Diārio Oficial, Brasilia, 19 de janeiro de 1977, p.710.

57 - COMITE dE EXPERTOS DE LA OMS EN ASPECTOS MICROBIOLOGI COS DE LA HIGIENE DE LOS ALIMENTOS REUNIDOS COM PARTICIPACION DE LA FAO, Ginebra, 1976. Informe. Ginebra, OMS, 1976 (OMS.ser.inf.tecn., 598).

58 - COMITE MIXTO FAO/OMS DE EXPERTOS EN ADITIVOS ALIMENTARIOS, Roma, 1980. $24^{\circ}$ informe Ginebra, OMS, 1980. (OMS-ser.inf.tecn., 653).

59 - COMITE MIXTO FAO/OMS DE EXPERTOS EN ADITIVOS ALIMENTARIOS, Ginebra, 1981. $25^{\circ}$ informe. Ginebra, OMS, 1981. (OMS - serv.inf.tecn., 669).

60 - Cook, et al. - The incidence and sources of penicilin in milk supplied to the city of Johannesburg. J.S. Afr. vet. med. Ass., 47:205-7, 1976 .

61 - CORREA, W.M. \& CORREA, C.N.M. - Mastites. Enfermidades infecciosas dos mamíferos domésticos. São Paulo, J.M. Varela Livros s.d., p. 110-23, 134. 
62 - DECRETO no 1255 de 25 de junho de 1962. Altera o Decre to nọ 30691 de 29 de março de 1952, que aprovou o re gulamento de Inspeção Industrial e Sanitāria.

63 - Della ROSA, H.V. \& MORAES, E.C.F. - Determinação de residuos de aflatoxina $M_{1}$ em leite, por fluordensitome tria. Rev. Farm. Bioguim. Univ. S. Paulo, 17:270$80,1981$.

64 - DODD, F.H. - Mastitis: progress on Control. J. Dairy Sci., $66: 1773-80,1983$.

65 - DULLEY, J.R. \& HOULIHAN, D. B. - An examination of queensland milk cheese for possible aflatoxin contamination. Aust. J. Dairy Technol., 34:12-3, 1949.

66 - DUMAIS, R. - L'effect nuisible de la peniciline dans a lait sur les ferments lactiques e le fromage Ceddar. Lait, 10:14-6, 1951 .

67 - DURRELL, W.B. - An evaluation of neomicin oitments for the treatment of clinical mastitis in dairy cattle. Corne11. Vet., 49:429-38, 1959.

68 - DUTHIE, I.F. et a 1. - Toxic groundunt meal in fedds por pigs. Vet. Rec., 82: $427-30,1968$.

69 - EDDS, Acute aflatoxicosis: a review. J. Amer. vet. med. Ass., 162:304-9, 1973. 
70 - EDDS, G.T. et al. - Alfatoxin incidence in feeds, toxicology and possible residue hazards in foods. Proc. Annu. Meet. UD. Anim. H1th Ass., 84:301-9, 1980.

71 - EDWARDS, G.S. \& WOGAN, G.N. - Aflatoxin inhibition of template activity of ra $t$ liver chromatin. Biochim. biophys. acta, Amsterdam, 224:597-607, 1970 .

72 - EGAN, J. et al. - Milk out rates for intramammary antibiotic preparations. Irish J. Food Sci.Technol., $\underline{5}: 129-41,1981$.

73 - EMANI, A. et a1. - La contamination des graines du cotonnier e des tourteaux de ces grains par l'aflato xine. Ann. Nutr., 31:531-7, 1977.

74 - ERSKINE, D. - Dermatitis caused by penicillin in milk. Lancet, 1:431-2, 1958 .

75 - FAgundes, C.M. - Persistência de antibiōticos no leite bovino e em condições experimentais. Rev. Inst. Laticinios Candido Tostes, 36:27-30, 1981 .

76 - FAgundes, C.M. et a 1. - Prevalēncia de antibiōticos no leite tipo "B" e "C" consumido em Belo Horizonte. Arq. Esc. Vet. UFMG, 34:203-6, 1982.

77 - FERrando, R. \& truhaut, R. - La toxicité de relais. Nou velle approche pour la méthodologie d'evaluation toxicologique des additifs aux animaux d'élevage. C.R. Acad. Sci. Paris, sēr. D. 278: 2067, 1972. 
78 - FERREIR0, L. et al. - Influência da mastite bovina sub-clínica na produção de gado mestiço. Arq. Fac. Vet. UFRGS, P. Alegre, $7: 135-43,1979$.

79 - FOLEY, E.J. et al. - Studies on vehicles for sustaining penicillin levels in the bovine Mammary Gland. Amer. J. vet. Res., 10:66-70, 1949 .

80 - FOOD AND DRUG ADMINISTRATION. Whole milk, lowfat milk, skim milk. Adulteration aflatoxin M. Guideline 7406-06, 1977. Apud STOLOFF, L. - Aflatoxin $\underline{M}$ in perspective. J.Food Protec., 43: 226-30, 1980 .

81 - FOOD AND DRUG ADMINISTRATION. Aflatoxin contamination of milk. Establishiment of action level. Federal Regist. 42-61630, 1970. Apud STOLOFF, L. - Aflatoxin $M$ in perspective. J. Food Protec., 43: 226-30, 1980 .

82 - FONSECA, H. - Contribuição ao estudo da ocorréncia de Aflatoxina em tortas, farelos e farinhas de Amendoim (Arachis Hypogaea L.) no Estado de São Paulo. An. Esc. sup. Agric. Luiz de Queiroz, 25:47-9, 1968.

83 - FONSECA, H. \& DEL NERY, H. - Ocorrēncia de Aflatoxina em pastas de Amendoim. An. Esc. sup. Agric. Luiz de Queiroz, 28: 181-90, 1970 .

84 - FOSTER, J.W. \& WOODRUFF, H.B. - Microbiological aspects of penicillin. I. Methods of Assay. J.Bacteriol., 46 : $187-202,1943$. 
85 - FREMY, J.M. \& ROILAND, J.C. - Devenir de 1'aflatoxine $M_{1}$ au cours de la fabrication du fromage de type camembert. Ann. Nutr., 33: 619-30, 1979 .

86 - FREMY, J.M. et al. - Evaluation de la contamination en Aflatoxine $M_{1}$ dans le lait en poudre par H.P.L.C. for phase invērseé. Ann. Fals. Exp. Chim., 74: $547-54,1981$.

87 - FRITZ, W. et al. Bestimmung und Vorkommen von Aflatoxin $M_{1}$ und $B_{1}$ in Milch und Milchprodukten. Die Nahrung, 21: $79-84,1977$.

88 - FURTADO, R.M. - Aflatoxin residues in the tissues of pigs fed a contaminated diet. J.Agric. Food Chem., 27: $1351-4,1979$.

89 - GELDA, C.S. \& LUYT, L.J. - Survey of aflatoxin content in peanuts, peanut buttler, and other foodstuffs. Ann. Nutr., 31: 477-83, 1977.

90 - GRANT, D.W. \& CARLSON, W.E. - Partitioning behavior of aflatoxin $M$ in dairy products. Bull Environ. Contam. Toxicol., 6 : 521-4, 1971 .

91 - GRAY, D.M. \& SCHALM, 0.M. - Interpretation of the California Mastitis test results on milk from individual mamary quarters, bucket milk, and bulk herd milk. J. Amer. vet. med. Ass., 136: 195-8, 1960 .

92 - GRUNERT, E. \& BIRGEL, E.H. - Obstetrícia veterināria. Porto Alegre, Editora Sulina, 1982, p. 288, 308-9, 312. 
93 - gUERGUE, I \& RAMIREZ, C. - Incidence of aflatoxin potential contamination of Spanish Sausages. Ann. Nutr., $31: 485-8,1977$.

94 - HALD, B. \& KROGH, P. - Forekomst of aflatoksin i importerede bomuldsfrøprodukter. (occurrence of aflatoxin in imported cottonseed products). Nord. Vet. Med., 22: $39-47,1970$.

95 - HAMILTON, P.B. - Proof of mycotoxicoses being a field problem and a simple method for their control. Poult. Sci., 54: 1706-8, 1975 .

96 - HANSEN, H.C. et al. - Modern methods of mastitis treattment cause trouble in the manufacturing of fermented dairy products. J. Milk Food Technol., 13: $359-65,1950$.

97 - HANSEN, E. \& JUNG, M. - Control of aflatoxins in the food industry. Pure Appl. Chem., 33: 239-50, 1973.

98 - HARGROVE, R.E. et a 1. - The effect of peniciliin and streptomycin on swiss cheese startes. J. Dairy Sci., 33: 401,1950 .

99 - HAYES, A.W. - Biological activities of mycotoxins. Mycopathologia, 65: 29-41, 1978 .

100 - HAWKINS, G.E. et al. - Concentration of penicillin in milk from non-infused quarters following infusion of one quarter. J. Dairy Sci., 45: 1020-2, 1962. 
101 - HESSELTINE, C.W. - Natural occurence of mycotoxins in cereals. Mycopathologia, 53: 141-53, 1974 .

102 - HeSSELTINE, C.W. et al. - Aflatoxin and mold flora in Norht Carolina in 1977 corn crop. Mycologia, 73: $216-28,1981$.

103 - HIBBS, R.A. \& BOYD, J.C. - Some observations on testing milk samples for antibiotics. J. Milk. Food Technol., 20: $109-12,1957$.

104 - HOLZAPFEL, et al. - Isolation and structure of aflatoxins $M_{1}$ and $M_{2}$. Tetrahedron Lett., 25: 2799-805, 1966.

105 - HUGHES, D.L. - Some epidemiological patterns in bovine mastitis. Vet.Rec., 72: 485-98, 1960.

106 - HUNTER, G.J.E. - The effect of penicillin on lactic streptococci. J. Dairy Res., 16: 39-45, 1949.

107 - HUNTER, G.J.E. - A note on the effect of penicillin in the redutase test for milk quality. J. Dairy Res., 16: $149-51,1949$.

108 - HUNTER, G.J.E. - The effect of penicillin in milk on the manufacture of cheddar cheese. J. Dairy Res., 16: $235-41,1949$.

109 - HUNTER, G.J.E. - The effect of penicillin in milk on the manufacture of cheddar cheese. J. Dairy Res., 16: $253-4,1949$. 
110 - Instituto AdOLfo LUTZ. Normas analîticas. 2a. ed. São Pau10, 1976. v.1, p. 166-7.

111 - JACKSON, W.F. \& BRYAN, C.S. - Penicillin milk levels in cows following intramammary administration. Vet. med., $45: 395-9,1950$.

112 - JACQUET, J. - La presence d'antibiotiques dans le lait et ses consequences pour l'industrie laitere. Proc. $13^{\text {th }}$. Intern. Dairy Congr., 1143-5, 1953. Apud: ALBRIGHT, J.L. et, al. Antibiotics in milk: a review. J. Dairy Sci., 44: 779-807, 1961 .

113 - JESTER, W.R. et a 1. - Antibiotics in fluid milk. Antib. and Chemother., 9: $393-5,1959$.

114 - JOHNS, C.K. - Differences in sensitivity of lactic starters to anbiotics. J. Dairy Sci., 36: 1241-7, 1953.

115 - JOHNS, C.K. \& DESMARIS, J.G. - The effect of residual penicillin in milk on the dye reduction lests for quality. Canad. J.Agric. Sci., 33: 91-7, 1953.

116 - JOHNSON, M.E. - Persistence of Antibiotics in Milk from Cows treated late in the dry period. J. Dairy Sci., 60: 1655-61, 1977 .

117 - JONES, M.G.S. \& EWART, J.M. - Effects on milk production associated with consumption of decorticated extracted groundnut mea 1 contaminated with aflatoxin. Vet. Rec., 105: 492-3, 1979. 
118 - JUNG, M. \& HANSSEN, E. - Uber das Vorkommen von Aflatoxin $M$ in Trockenmilcherzengnissen. Food Cosmet. Toxicol., 12: $131-8,1974$.

119 - JUSZKIEWICZ, T. \& PISKORSKA-PLISZCZYNNSKA - Z awarto $\bar{S} \overline{\mathrm{C}}$ aflatoksyn $B_{1}, B_{2}, G_{1} i G_{2}$, ochratoksyn $A$ i $B$, sterygmatocystyny $i$ zearalenonu $W$ srutach zbozowych. occurrence of aflatoxins $B_{1}, B_{2}, G_{1}$ and $G_{2}$ ochratoxins $A$ and $B$, sterigmatocystin and zearalenone in cereals). Med. Wet., 32: 617-9, 1976.

120 - JUSZKIEWICZ, T. \& PISKORSKA-PLESZCZYNSKA - Mycotoxins in grain for animal feeds. Ann. Nutr., 31: 489-93, 1977 .

121 - KATZ, S.E. et al. - oxytetracycline residues in milk following intramammary infusion. J. Ass. Offic. Ana 1. Chem., 56: 706-13, 1973.

122 - KATZNELSON, H. \& HOOD, E.G. - Penicillin in Relation to acid production in milk by starter culture used in cheeddar cheesemaking. Science, 109: 490-1, 1941.

123 - KATZNELSON, H. \& HOOD, E.G. - Influence of penicillin and other antibiotics on lactic streptococci in starter cultures used in cheddar cheesemakin. $\mathrm{J}$. Dairy Sci., 32: 961-8, 1949.

124 - KEPPLER, J.G. \& IONGH, H. - Aflatoxin - ocurrence and composition. Food Cosmet. Toxicol., 2: 675-7, 1964. 
125 - KERSEY, R.C. et a1. - Residual antibiotics levels in food products during storage and processing. Antibiot. Ann., p. 438-48, 1953-54.

126 - KIERMEIER, F. - Aflatoxin residues in fluid milk. Pure Appl. Chem., 35: 271-4, 1973.

127 - KIERMEIER, F. - The significance of aflatoxins in the dairy industry. Apud: WORLD HEALTH ORGANIZATION.

Mycotoxins. Geneva, 1979. p. 40. (WHO - Environmental healt criteria, 11).

128 - KIERMEIER, F. \& BUCHNER, M. - Verhalten von Aflatoxin $M_{1}$, whthend der Reifung und Lagerung von Kase. $\underline{Z}$. Lebensmitt-Untersuch., 164: 87-91, 1977.

129 - KINOSITA, R. et al. - Mycotoxins in fermeted foods. Cancer Res., 28: 2296-311, 1968.

130 - KONG, Z.F. et äl. - Studies on the secretion of aflatoxin $M_{1}$ in cow's milk after aflatoxin $B_{1}$ feeding. Acta vet. zootech. sin., 13(3): 119-204. Apud: Veterinary Bulletin, 53: 63, 1983. |resumo|.

131 - KOSIKOWSKI, F.V. et al. - The incidence of antibiotics, sulfa drugs and quarternary ammonium compounds in the fluid milk supply of New York State. J. Dairy Sci., 35: $533-9,1952$.

132 - KOSIKOWSKI, F.V. - The control of antibiotics in milk through a sound test program. J. Milk Food Technol., 23: $285-7,1960$. 
133 - KRIENKE, W.A. - Effects of various drugs in milk from mastitis treated cows. Sth. Dairy Prod. J., 47: $37,132-4,1950$.

134 - KRIENKE, W.A. - Penicillin in milk. Amer. Milk Rey., 11: $24-5,1950$.

135 - KRIENKE, W.A. - Drug, mastitis and acid starters. Amer. Milk Rev., 12:54-6, 1950.

136 - KRISHNAMACHARI, K.A. et a1. - Hepatitis due to aflato- $\chi$ xicosis. An outbreak in Western India. Lancet, 1: $1061-3,1975$.

137 - KROGH, P. - Mycotoxin tolerances in foodstuffs. Ann. Nutr., $31: 411-4,1977$.

138 - KROGH, P. \& HALD, B. - Forekomst of aflatoxin i importerede jordnødprodukter (occurrence of aflatoxin in imported groundnut products. Nord. Vet. Med., 21: 398-407, 1969.

139 - KROGH, P. et a1. - Forekmost af aflatoksin in jordn $\varnothing d-$ -og Kokosprodukter indførf til Finland. (Occurence of aflatoxin in groundnut - and copra products imported to Fintand). Nord. Vet. Med., 22: 584-9, 1970 .

140 - KROGH, P. et al. - Aflatoxin residues in bacon pigs. Pure App 1. Chem., 35: 275-81, 1973. 
141 - KRUZE, J. \& BRAMLEY, A.J. - Sources of Streptococcus uberis in the dairy herd. II. Evidence of colonization of the bovine intestine by streptococcus uberis. J. Dairy Res., 49: 375-9, 1982.

142 - LABUZA, T.P. - Regulation of mycotoxins in foods. J. Food Protec., 46: 260-5, 1983.

143 - LACERDA Jr., P.M.G. et al. - Studies on bovine mastitis. In: Congresso Panamericano de Medicina Veterinária, 12, São Paulo, 1954. Anais. São Paulo, p.209.

144 - LACERDA Jr., J.P.G. \& VEIGA, J.M.S. - Mastite em egua causada pelo Corynebacterium equi. Rev. Fac. Med. vet. e Zoot. Univ. S. Paulo, 6: 321-7, 1959.

145 - LAFONT, P. - Recherche et dosage d'aflatoxine dans les aliments pour enfants. Ann. Hyg. L., (France), 11: $47-9,1975$.

146 - LAFONT, P. \& LAFONT, J. - Contamination de produits céréaliers et d'aliments du bétail par l'aflatoxine. Food Cosmet. Toxico1., 8: 403-8, 1970 .

147 - LAFONT, P. et a 1. - Etude de la contamination du lait de vache lors de l'ingestion de faibles quantites d'Aflatoxine. Ann. Nutr., 34: 699-708, 1980.

148 - LANCASTER, M.C. et al. - Toxity associated with certain samples of groundnut. Nature, 192: 1095-6, 1961.

149 - LANDREY, J.S.A. - The effect of mastitis on herd milk production and composition. J.S. Afr. vet. med. Ass., 36: $515-9,1965$. 
150 - LARA, W.H. - Aditiyos para alimentos. Hig. Alim., I: $148-50,1982$.

151 - LEWIS, G. et al. - The effect of feeding toxic groundnut meal to sheep over a period of 5 years. Vet. Rec., 80: $312-4,1967$.

152 - LIE, J.L. \& MARTH, E.H. - Formation of aflatoxin in Cheddar cheese by Aspergillus flavus and Aspergillus parasiticus. J. Dairy Sci., 50: 1708-10, 1967.

153 - LING, K.H. et a1. - Aflatoxin $B_{1}$ in unrefined peanut oil and peanut products in Taiwan. J. Formosan Med. Ass., 67: 309-14, 1968 .

154 - LÖTZSCH, R. \& LEISTNER, L. - Transmission of aflatoxins into eggs and egg products. Ann. Nutr., 31: 494$508,1977$.

155 - LOOSMORE, R.M. \& HARDING, J.D.J. - A toxic factor in Brazilian groundnut causing liver damage in pigs. Vet. Rec., 73: 1362-4, 1961 .

156 - LOOSMORE, R.M. \& MARKSON, L.M. - Poisoning of cattle by Brazilian groundnut mea1. Vet. Rec., 73:813-4, 1961 .

157 - LUCAS Jr., F.V. et al. - Mycotoxin contamination of Sout Vietnamese rice. J. trop. Med. Hyg., 74: $182-3,1971$. 
158 - LUCK, H. - The manufacture of cheese from milk preserved with $\mathrm{H}_{2} \mathrm{O}_{2}$ (hydrogen-peroxide). Dairy Sci. Abstr., 18: 32,1956 .

159 - LUCK, H. - The use of hydrogen - peroxide as a dairy preservative. Dairy Sci. Abstr., 18: 363-85, 1956.

160 - LYNCH, G.P. - Mycotoxins in feedstuffs and their effect on dairy cattle. J. Dairy Sci., 55: 1243-55, 1972.

161 - MACEDO, L.R. et al. - Antibióticos no leite. Rev. Inst. Laticinios Cândido Tostes, 31: 21-4, 1976.

162 - MAIKE, J. \& HANSSEN, E. - Über das Vorkommen Von Aflatoxin $M$ in Trockenmilcherzeugnssen. Food Cosmet. Toxico1., 12: 131-8, 1974.

163 - MARCINIAK, T. - Factors affecting the contamination milk after administration into the cow's uterins. Med. Weter, 38 : $141-4,1982$.

164 - MARTH, E.H. - Aflatoxin in milk and milk products. J. Food Protec., 42: $841,1979$.

165 - MARTH, E. H. - Antibiotics in milk - A review. J. Milk Food Technol., 24: $36-44,1961$.

166 - MARTH, E.H. \& ELLICKSON, B.E. - Antibiotic Residues in milk products. J.Milk Food Technol., 22: 241 9 , 1959. 
167 - MARTH, E.H. \& ELLICKSON, B.E. - Problems created by the presence of antibiotics in milk and milk products. J. Milk Food Technol., 22: 266-72, 1959.

168 - MASRI, M.S. - Crystaline aflatoxin $M_{1}$ from urine and mi1k. Nature, London, 215: 753-5, 1967.

169 - MASRI, M.S. et al. - Aflatoxin M content of milk from cows fed known amounts of aflatoxin. Vet. Rec., 84: $146-7,1969$.

170 - MARTIN, W.H. et al. - Aureomycin contet, bacterial development, starter activity and cheese quality of milk from cows fed an aureomycin supplement. Dairy Sci., 38: 47-52, 1955.

171 - MAUpoume, R. - Mammite des femelles bovines: prophylaxie et therapeutique. L'emploi des antibiotiques e leur répercussion sur la qualité ds produits laiters. Bul1. off. int. Epizooties, 40: 208-23, 1953.

172 - MCCULLOCH, E.C. et a1. - Aureomycin in the treatment of Staphylococcic Mastitis in cows. Vet. Med., 44: 253,1949 .

173 - MCKINNEY, J.D. et a1. - Effects of ammoniation of aflatoxins in rations fed lacting cows. J. Amer. 0i1 Chem. Soc., 50:79-84, 1973.

174 - MEARA, 0.J. - A survey of penicillin contamination of market milk supplies. S. Afr.med. J., 33: 821-2, 1959 . 
175 - MELLER, A.C. - Antibiöticos no leite cru consumido na cidade de Santa Maria, R.S. Rev. Centro Ciēncias Rurais, 4 : $169-72,1974$.

176 - Mello filho, A. - Utilização da āgua oxigenada no tra tamento do leite cru destinado ao consumo. Rev. Inst. Laticinnios Cândido Tostes, 28: 37-40, 1973.

177 - MEllo filho, A. \& CASTRo, L.C. - Conservação do leite "in natura" por meios físicos, químicos e bioquími cos, peróxido de hidrogénio como conservador. Rev. Inst. Adolfo Lutz, 29/30: 85-103, 1969/70.

178 - MELLO FILHO, A. et a 1. - Inibidores bacterianos no leite de consumo da capital. Rev. Inst. Adolfo Lutz, 25/27: 69-93, 1965/67.

179 - MELlo Filho, A. et al. - Inibidores bacterianos em especial a penicilina, no leite em pó de consumo da capital. Rev. Inst. Adolfo Lutz, 28: 27-41, 1968.

180 - MERCER, H.D. et al. - Milk out rates for antibiotics in intramammary infusion products used in the treatment of bovine mastitis. Relationship of somatic cell counts, milk production level and drug vehicle. Amer. J.Vet. Res., 31: 1549-60, 1970 .

181 - Ministério da Agricultura - Divisão de Inspeção de Produtos de Origem Animal. Portaria nọ 005 de 24 de abril de 1980. Diārio Oficial, Brasīia, 25 de abri1 de 1980, p. 7349. 
182 - Ministērio da Agricultura - Divisão de Inspeção de Pró dutos de Origem Animal. Portaria no 0005 de 07 de março de 1983. Diärio Oficial, Brasília, 14 de mar ço de 1983, p. 4084 .

183 - MOREAU, C. - Les mycotoxins dans les produits laiters. Lait, $(555-556): 286-303,1976$.

184 - MOREIRA, E.A. \& CAMATI, R.M. - Ocorrēncia da aflatoxina $B_{1}$ em alfafa (Medicago $s p$ ) contaminado pelo Aspergillus flavus-orizal. Trib. Farmacêut., 36: 2732,1967 .

185 - NABNEY, J. et al. - Metabolism of aflatoxin in sheep: excretion pattern in the lactating ewe. Food Cosmet. Toxicol., 5: 11-7, 1967.

186 - NEAL, C.E. \& CALBERT, H.E. - Incidente of lactic starter inhibitory substances in individual herd milks of Wisconsin. Milk Prod. J., 47: 18-21, 1956.

187 - NELF, G.L. \& EDDS, G.T. - Aflatoxins $B_{1}$ and $M_{1}$ : Tissue residues and feed withdrawal profiles in young growing pigs. Food Cosmet. Toxicol., 19: 739-42, 1981.

188 - NEWBERNE, P.M. \& BUTLER, W.H. - Acute and chronic effects of aflatoxin on the liver of domestic and laboratory animals. Cancer Res., 29: 236-50, 1969.

189 - NEWBERNE, P.M. et a 1. - Acute toxicology of aflatoxin $B_{1}$ in the dog. Patho1. Vet, $\underline{3}: 331-40,1966$. 
190 - NEWLANDER, J.A. \& ATHERTON, H.V. - The chemistry and testing of dairy products. 3a. ed. Milwaukec, Wisconsin, 01sen Publishing, 1964. p. 201.

191 - NIKOLOV, N. - Effects of antibiotics on the microflora of yogurt. Dairy Sci. Abstr., 29: 75, 1966.

192 - O'DONOVAN, D. et al. - The effect of udder infections on the lactation yield of milk and milk solids. J. Dairy Res., 27: 115-20, 1960 .

193 - O'REILLY, P.F. - A survey of the incidence of antibiotics contamination of milk in the Dublin liquid milk area. Irish vet. J., 26: 41-7, 1970.

194 - PATTERSON, D.S.P. \& ALLCROFT, R. - Metabolism of aflatoxin in susceptible and resistant animal species. Food Cosmet. Toxicol., 8: 43-53, 1970.

195 - PATTERSON, D.S.P. \& ANDERSON, P.H. - Recent aflatoxin feeding experiments in cattle. Vet. Rec., 110: 60,1982 .

196 - PATTERSON, D.S.P. et a1. - The carry over of aflatoxin $M_{1}$ into the milk of cows fed rations containing a low concentration of aflatoxin $B_{1}$. Food Comest. Toxico1., 18: $35-7,1980$.

197 - PEARSON, J.K.J. - Further experiments in the use of penicillin in the prevention of $C$. pyogenes infections of the non-lacting bovine udder. Vet. Rec., 63: $215-22,1951$. 
198 - PLASTRIDGE, W.N. - Bovine mastitis: A review. J. Dairy Sci., 41: 1141-81, 1958 .

199 - POLAN, C.E. et a 1. - Consumption and fate of aflatoxin ${ }_{1}$ by lactating cows. J. Agric. Food Chem., 22: $635-8,1974$.

200 - POLO LARA, R. et al. - Antibiotics in milk from suthern Spain. Arch. Zootech., 26: 125-45, 1977.

201 - PONG, R.S. \& WOGAN, G.N. - Toxicity and biochemical and fine structural effects of synthetic aflatoxins $M_{1}$ and $B_{1}$ in rat 1iver. J. nat. Cancer Inst., 47: $585-90,1971$.

202 - POZZOBON, E.D.T. et a 1. - Determinação de aflatoxina $M_{1}$ em leite cru consumido na cidade de Santa Maria. Rev. Centro Ciēncias Rurais, 6: 423-5, 1976.

203 - PRIOR, M.G. - Mycotoxin determinations on animal feedstuffs and tissues in Western Canada. Canad. Compr. Med., 40: 75-9, 1976.

204 - PUGH, K.E. et al. - Evaluation of a long-acting intramammary preparation containing high doses of penicillin and streptomycin for use in dry cows. Vet. Rec., 93: 212-6, 1973 .

205 - PURCHASE, I.F.H. - Acute toxicity of aflatoxins $M_{7}$ and $M_{2}$ in one-day-old ducklings. Food Cosmet. Toxicol., ㄴ: $339-42,1967$. 
206 - PURCHASE, I.F.H. - Aflatoxin residues in food of animal origin. Food Cosmet. Toxicol., 10: 531-44, 1972 .

207 - PURCHASE, I.F.H. \& VORSTER, L.J. - Aflatoxin in commercial milk samples. S. Afr.med. J., 42: 219,1968 .

208 - PURCHASE, I.F.H. et al. - Reduction of the aflatoxin $M$ content of milk by processing. Food Cosmet. Toxicol, 10: $383-7,1972$.

209 - PURCHIO, A. - Pesquisa de aflatoxina $B_{1}$ e substāncias fluorescentes similares em farinha de trigo. Rev. Microbiol., 1: $33-42,1970$.

210 - QUTET, S.M. et al. - Occurrence of aflatoxins in some egyptian food crops collected from two coastal regions. Food Chem., 10: 149-53, 1983.

211 - RAJ, P. et al - Incidence of aflatoxins in milk and milk products. Indian J. Dairy Sci., 29: 318-21, 1976 .

212 - REIS, R. et al. - Estudo sobre penicilina no leite. II. Pesquisas de penicilina no leite recebido pela cooperativa central dos produtores rurais de Belo Horizonte, Minas Gerais. Arq. Esc. Vet., 15: 81$91,1963$.

213 - REPORT of the panel of the coloquium on bovine mastitis. J. Amer. vet. med. Ass., 170:119-23, 1977. 
214 - RICHARDS, R.J. et al. - Antibiotics resistence and acid production cultures belonging to the Genus Streptococcus. J.Milk Food Technol., 24: 317-20, 1961.

215 - ROGERS, A.E. \& NEWBERNE, P.M. - Aflatoxin $B_{1}$ carcinogenesi in lipotrope-deficient rats. Cancer Res., 29:196572,1969 .

216 - RUIZ, R.L. - 0 problema das mastites nos bovinos. Pre venção e tratamento. Hig. Alim., 2: 55.63, 1983.

217 - RUSSEL, T.E. et al. - Field accumulation of aflatoxin in cotton-seed as influenced by irrigation termination dates and pink bollworn infestation. Appl. Environ. Microbiol., 31: 711-3, 1976.

218 - SABINO, M. - Variações de nĩveis de aflatoxina $B_{1}$ em alimentos e rações animais no período de 1971 a 1979. Rev. Inst. Adolfo Lutz, 40: 153-8, 1980.

219 - SABINo, M. - Inquērito sobre aflatoxina "M" no leite de vaca comercializado no Estado de São Paulo. Padronização de método analitico por cromatografia lïquida de alta resolução. São Paulo, 1983 |Dis sertação de mestrado - Faculdade de Ciēncias Farma cēuticas - USP|.

220 - SABINO, M. \& CORREA, M.J.S. - Aflatoxin B 1 em feijão. Rev. Inst. Adolfo Lutz, 41: 83-7, 1981. 
221 - SABINO, M. et al. - Variação dos nỉveis de aflatoxina $B_{1}$ em pasta de amendoim e paçoca consumidas no Esta do de São Paulo. Rev. Inst. Adolfo Lutz, 42: $39-$ 44,1982 .

222 - SAMARAJEIWA, $V$. - Spontaneous and experimental aflatoxicosis in goats. Res. Vet. Sci., 19: 269-77, 1975.

223 - SARGENT, K. et al. - The assay of a toxic principale in Brazilian groundnut meal. Vet. Rec., 73: 121923,1961 .

224 - SARGENT, K. et a1. - Toxicity associated with certain samples of groundnuts. Nature, London, 192: 10967,1961 .

225 - SCHIPPER, I.A. - Comparison of vehicles in intramammary therapy of bovine mastitis. Vet. Med., 50: 111-3, 1955.

226 - SCHNEIDER, S. et a 1. - Determination of aflatoxin and aflatoxin producing cultures in recently ginned cotonseed in Central America. J.Amer. 0 il Chem. Soc., $49: 700-1,1972$.

227 - SCHOECH, P.R. - Testing for antibiotics in milk. Field observations. J. Food Protec., 40: 138-41, 1977.

228 - SCHROEDER, H.W. \& BOLLER, R.A. - Aflatoxin production of species and strains of the Aspergillus flavus ${ }^{-0}$ group isolated from field crops. Appl. Microbiol., 25: 885-9, 1973. 
229 - SChULLER, P.L. et a 1. - Aflatoxin $M_{1}$ in liquid and powdered milk. Zesz. probl. Postep. Nauk roln., 189: 255,1977 .

230 - SCHULTZ, J. \& MOTZ, R. - Toxinbildende Aspergillus flavus. Stamme in Futtermitteln. Arch. exp. Vet. Med., 21: $129-40,1967$.

231 - SCOTT, P.M. - Mycotoxins in feeds and ingredients and their origin. J.Food Protec., 41: 385-98, 1978.

232 - SCOTT, R. - Destruction of starter activity by penicillin. Dairy Ind., 16:440-3, 1951.

233 - SHAHANI, K.M. et al. - Stability of small concentration of penicillin in milk as affected by heat treatment and storage. J. Dairy Sci., 39: 971-7, 1956.

234 - SHAHANI, K.M. - The effect of heat and storage on the stability of aureomycin in milk, buffer and water. J. Dairy Sci., 40: 289-96, 1957.

235 - SHANK, R.C. et a 1. - Dietary aflatoxins and human liver cancer. I. Toxigenic moulds in foods and foodstuffs of tropical southeast. Asia. Food Cosmet. Toxicol., 10: $51-60,1972$.

236 - SHIVELER, G. \& WEISER, H. - The effect of selected antibiotics upon the survival of microorganisms in raw and pasteurided milk. J. Milk Food Technol., 16: $125-7,1953$. 
237 - SHOTWELL, 0.L. - Mycotoxins in hot spots in grains.

I. Aflatoxin and zearalenone ocurrence in stored corn. Cereal Chem., 52: 687-97, 1975.

238 - SHOTWELL, O.L. - Aflatoxin $M_{1}$. Ocurrence in stored and freshly harverted corn. J.Agric. Food Chem., 24: $683-4,1976$.

239 - SHOTWELL, 0.L. - Aflatoxin in corn. J.Amer. 0 il Chem. SoC., 54: 216A-24A, 1977.

240 - SHOTWELL, 0.L. et a1. - Survey of cereal grains and soybeans for the presence of aflatoxin. I. Wheat, grain sorghum and oats. Cereal Chem., 46: 446-54, 1969.

241 - SHOTWELL, 0.L. et a1. - Survey of cereal grains and soybeans for the presence of aflatoxin. II. Corn and soybeans. Cereal Chem., 46: 454-63, 1969.

242 - SHOTWELL, 0.L. et al. - Survey of corn for aflatoxin, zearalenone and ochratoxin. Cereal Chem., 47:7007,1970 .

243 - SHOTWELL, 0.L. et a1. - Incidence of aflatoxin in southern corn. Cereal Sci. Today, 18: 192-5, 1973.

244 - SHOTWELL, 0.L. et a 1. - Survey of U.S. Wheat for ochratoxin and aflatoxin. J.Ass. Off. Anal.Chem., 59: $122-4,1976$. 
245 - SHOTWELL, 0.L. et a1. - Survey of 1975 wheat and soybeans for aflatoxin, zearalenone and ochratoxin. J.Ass. Off. Anal. Chem., 60: 778-83, 1977.

246 - SHREEVE, B.J. et al. - Investigation of suspected cases of mycotoxicosis in farm animals in Britain. Vet. Rec., $97: 275-8,1975$.

247 - SIDDIQUE, I.H. et al. - Antibiotic residues in milk transferred from treated to untreated quarters in dairy cattle. J. Amer. vet. med. Ass., 146:589-93, 1965 .

248 - SINNHUBER, R.0. et al. - Aflatoxin $M_{1}$, a potent 1 iver carcinogen for rainbow trout. Fed. Proc., 29: 568 (Abstr.), 1970 .

249 - SINNHUBER, R.0. et al. - Hepatic carcinogenesis of aflatoxin $M_{1}$ in rainbow trout (Salmo gairdneri) and its enhancement by ciclypropene fathy acids. J. nat. Cancer Inst., 53: 1285-8, 1974.

250 - SinNhUBER, R.0. \& WALES, J.H. - Aflatoxin $B_{1}$ hepatocarcinogenicity in rainbow trout embryos. Fed. Proc., 38: $274,1974$.

251 - SLANeTZ, L.W. \& ALLEN, F.E. - Penicillin therapy in Stheptococcal mastitis. J.Amer. vet. med. Ass., 111: $125-7,1947$.

252 - SMITH, A. et al. - The persistence of cloxacillin in the mammary gland when infused immediately after the last milking of lactition. J. Dairy Res., 34: $47-57,1967$. 
253 - SMITH, A. et al. - The persistence of penicillin $G$ in the mammary gland when infused immediately after the last milking of lactation. J. Dairy Res., 34: $59-64,1967$.

254 - SMITH, J.W. \& HAMILTON, P.B. - Aflatoxicosis in the broiler chicken. Poultry Sci., 49: 207-15, 1970.

255 - SMITH, J.W. et a 1. - Survey of aflatoxicosis in farm animals. Appl. Environ Microbiol., 31: 385-8, 1976.

256 - STANDARD METHODS FOR THE EXAMINATION OF DAIRY PRODUCTS - American Public Health, 14 ed., Washington, D.C., $1978, \quad$ p. $141-50$.

257 - STEVENS, A.J. et a 1. - Investigations into descase of turkey poults. Vet. Rec., 72: 627-8, 1960.

258 - STOLOFF, L. - Report on mycotoxins.

J. Ass. Off.

Anal. Chem., 60: 348-53, 1977.

259 - STOLOFF, L. - Aflatoxin M in perspective.

J. Food

Protec., 43: $226-30,1980$.

260 - STOLOFF, L. \& WOOD, G. - Aflatoxin M in manufactured dairy products produced in the united states in 1979. J. Dairy Sci., 64:2426-30, 1981 .

261 - STOLOFF, L. et al. - Stability M in milk. J. Dairy Sci., 58: 1789-93, 1977 . 
262 - STOLOFF, L. et al. - Survey for aflatoxins and zearalenone in 1973 crop corn stored on farms and in country elevators. J.Ass. Off. Ana1. Chem., 59: 118-21, 1976 .

263 - STOLTZ, E.I. \& HANKINSON, D.J. - Antibiotics and lactic acid starter cultures. Appl. Microbiol.,
$1: 24-9,1953$.

264 - STOLTZ, E.I. \& HANKINSON, D.J. - The effects of antibiotics in milk on the human intestinal coliform bacteria. J. Milk Food Technol., 17: 76-8, 1954.

265 - STOLZ, E.I. \& HANKINSON, D.J. - The effects of antibiotics on the bacterial plate counts of normal raw milk. J. Milk Food Technol., 16: 157-9, 1953.

266 - STORRS, F.C. \& HIETT BROWN, W. - The incidence of penicillin. in milk supplies. J. Dairy Res., 21: $337-41,1954$.

267 - STRZELECKI, E.L. - Extraction and determination of Aspergillus flavus metabolites - aflatoxins from meat products. Pure App1. Chem., 35: 297-307, 1973.

268 - STRZELECKI, E.L. \& GASIOROWSKA, V.W. - Aflatoxin B in feedstuffs. Zzbl. vet. med., 21: 395-440, 1974.

269 - STUART JONES, M.G. \& EWART, J.M. - Effects of : milk production associated with consuption of decorticated extracted groundnut meal contaminated with aflatoxin. Vet. Rec., 105: 492-3, 1979. 
270 - Stubblefield, R.D. \& SHANNON, G.M. - Aflatoxin M 1 : Analysis in dairy products and distribution in dairy foods made from artificially contaminated milk. J.Ass. Off. Ana1. Chem., 57: 847-51, 1974.

271 - SUZANGAR, M. et a1. - Aflatoxin contamination of village milk in. ISFAHAN, IRAN - Trop. Sci., 18: 155-9, 1976.

272 - THOMAS, S.B. and PANES, J.J. - Further studies on the effects of penicilitin in milk used for the manufacture of cheshire chesse. 3. Soc. Dairy Technol., 9: 87$92,1956$.

273 - THORP, W.T.S. et al. - Concentration of penicillin in the bovine mammary gland following infusion penicillin tolerance of certain streptococci. Amer. J. vet. Res., 8: 157-65, 1947.

274 - TOMA, C. et a $T^{\circ}$. - Studies on the use of hydrogen peroxide for preserving milk for liquid consumption and processing. Dairy Sci. Abstr., 26: 417, 1964. $\mid$ resumo|.

275 - TREMBATH, R.H. - Effect of penicillin in milk on starter cultures. Aust. J. Dairy Technol., 5: 143-6, 1950.

276 - TRUCKSESS, M.W. - Aflatoxicol and aflatoxins $B_{1}$ and $M_{1}$ in the tissues of pigs receiving aflatoxin. J.Ass. Off. Anal. Chem., 65: 884-7, 1982.

277 - TUINSTRA, L.G.M. Th. \& BRONSGEEST, J.M. - Determination of aflatoxin $M_{1}$ in milk at the parts per trillion leve1. J.Cromatogr., 111: 448-51, 1975. 
278 - TUNG, H.T. \& HAMILTON, P.B. - Decreased plasma carotenoids during aflatoxicosis. Poult. Sci., 52: 80-3, 1973.

279 - ULBERG, S. et al. - Distribution of aqueous penicillin and penicillin in oil in normal goat udders following intramammary injection. An autoradiograph study. Amer. J. vet. Res., 19: 135-8, 1958.

280 - UVAROV, 0. - The concentration of some antibiotics in the milk after intramammary infusion. Vet. Rec., 72: $1228-32,1960$.

281 - VAID, J. et al. - Chronic aflatoxicosis in cattle. Vet. Hum. Toxicol., 23: $436-8,1981$.

282 - VAID, Y. et al. - Penicillin levels in milk following parenteral administration of procaine penicillin. J. Dairy Sci., 43: $842,1960$.

283 - Van EGMOND, H.P. - Mycotoxins in Dairy Products. Food Chem., 11: 289-307, 1983 .

284 - Van EGMOND, H.P. et al. - The effect of processing on the aflatoxin $M_{1}$ content of milk and milk products. Arch. Inst. Pasteur (Tunis), 54: 381-90, 1977.

285 - Van PEE, W. et a 1. - La detection et le dosage de 1 'aflatoxine $M_{1}$ dans le lait et le lait en poudre. Rev.Agr., 30: 403-14, 1977.

286 - VARSAVSKY, E. et al. - Aflatoxinas: Su detecciōn en mani y suelos de la Prov. de Cördoba, Rev. Asoc. argent. Microbiol., 5: 3-4, 1973. 
287 - VARSAVSKY, E. \& SOMMER, S.E. - Determination of aflatoxil in peanuts. Ann. Nutr., 31: 539-44, 1977.

288 - VICKERS, H.R. et al. - Dermatitis caused by penicillin in milk. Lancet, 1: $351-2,1958$.

289 - VIGUE, R.F. - Relative efficacy of three antibiotic combinations in bovine mastitis. J. Amer. vet. med. Ass., 124: $377-8,1954$.

290 - VOGEL, A.I. - Quimica analitica qualitativa. 5a. ed. São Paulo, Mestre Jou, 1981, p. 575.

291 - WAL, J.M. \& BORIES, G. - Elimination de pēnicilline libre et fixeē sois forme de conjugués penicilloy-proteins dans le lait de vache aprēs traitement par voie intramammaire. Ann. Biol. anim., 15:61517,1975 .

292 - WAL, J.M. - Evolution du concept de résidu dans les produits animaux des antibiotiques utilisés en élevage. Ann. Nutr., 33: 325-41, 1979.

293 - WEI, C. \& HSIEH, D.P.H. - Aflatoxin in human and animal health. Proc. Ann. Meet. U.S. Hith Ass., 84: $283-97,1980$.

294 - WELCH, H. - Problems of antibiotics in food as the Food and Drug Administration sees them. Amer.J. public H1th, $47: 701-5,1957$.

295 - WELCK, H. et al. - Antibiotics in fluid milk. Antib. and Chemother., $\underline{5}: 571-3,1955$. 
296 - WELCH, H. et al. - Antibiotics in fluid market milk. Antibiot. and Chemother., 6: 369-74, 1956.

297 - WELSH, H. et al. - Antibiotics in fluid milk. Antibiot. and Chemother., 5: $571-3,1955$.

298 - WESSEL, J.K. \& STOLOFF, L. - Regulatory surveillance for aflatoxin and other mycotoxins in feed, meat and milk. J. Amer. vet. med. Ass., 163: 1284-7, 1973.

299 - WILSON, B.J. - Hazards of mycotoxins to public health. J. Food Protec., $375-84,1978$.

300 - WISEMAN, D.W. \& MARTH, E.H. - Behavior of aflatoxin M in yogurt, buttermilk and kefir. J. Food Protec., 46: $115-8,1983$.

301 - WISEMAN, D.W. \& MARTH, E.H. - Stability of aflatoxin $M_{1}$ during manufacture and storage of a butter-like spread, non-fat dried milk and dried buttermilk. J. Food Protec., 46: 633-6, 1983.

302 - WISEMAN, D.W. \& MARTH, E.H. - Behavior of aflatoxin M during manufacture and storage of queso blanco and baker's cheese. J.Food Protec., 46: 910-3, 1983.

303 - WISEMAN, D.W. et a 1. - Distribution and resistence to pasteurization of aflatoxin $M_{7}$ in naturally contaminated whole milk, cream and skim milk. J.' Food Protec., 46: 530-2, 1983. 
304 - WISHART, D.F. - Antibiotics in milk. Vet. Ann., 23: $71-8,1983$.

305 - WITEHEAD, H.R. \& LANE, D.J. - The influence of penicillin on the manufacture and reppining of cheddar cheese. J. Dairy Res., 23: 355-60, 1956.

306 - WOGAN, G.N. - Chemical nature and biological effects of the aflatoxins. Bact. Rev., 30:460-70, 1966.

307 - WOGAN, G.N. et a 1. - Structure - activity relationship among aflatoxin and analogs. Acute toxicity and carcinogenic potency. Cancer Res., 31: 1936-42, 1971 .

308 - WOGAN, G.N. \& PAGLIALUNGA, S, - Carcinogenicity of shynthethic aflatoxin $M_{1}$ in rats. Food Cosmet. Toxico1, 12: $381-4,1974$.

309 - WRIGHT, C.L. - Antibiotic residues in milk. Vet. Rec., 108: 20,1981 .

310 - YNDESTAND, M. \& UNDERDAL, B. - Aflatoksin i naeringsmidler pa det. norske. marked. (Aflatoxin in foods on the Norwegian market). Nord. vet.-med., 27: 42-8, 1975.

311. - ZIMMERMAN, M.C. - Chronic penicillin urticaria from dairy products proved by penicilinase cures. Archs. Derm. Syph., 79: 1-6, 1959. 